\title{
Size-dependent wet removal of black carbon in Canadian biomass burning plumes
}

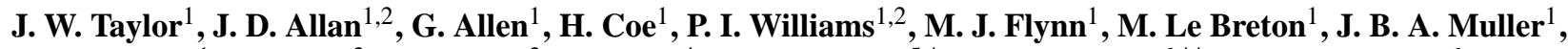

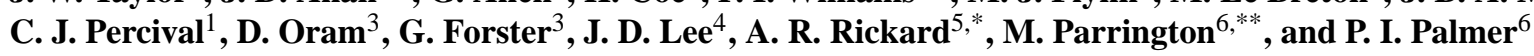 \\ ${ }^{1}$ Centre for Atmospheric Science, School of Earth, Atmospheric and Environmental Sciences, University of Manchester, \\ Manchester, UK \\ ${ }^{2}$ National Centre for Atmospheric Science, University of Manchester, Manchester, UK \\ ${ }^{3}$ National Centre for Atmospheric Science (NCAS), School of Environmental Sciences, University of East Anglia, \\ Norwich, UK \\ ${ }^{4}$ National Centre for Atmospheric Science (NCAS), Department of Chemistry, University of York, York, UK \\ ${ }^{5}$ National Centre for Atmospheric Science (NCAS), School of Chemistry, University of Leeds, Leeds, UK \\ ${ }^{6}$ School of GeoSciences, University of Edinburgh, Edinburgh, UK \\ *now at: the National Centre for Atmospheric Science (NCAS), Department of Chemistry, University of York, York, UK \\ ** now at: European Centre for Medium-Range Weather Forecasts, Shinfield Park, Reading, RG2 9AX, UK
}

Correspondence to: J. W. Taylor (jonathan.taylor@manchester.ac.uk)

Received: 1 July 2014 - Published in Atmos. Chem. Phys. Discuss.: 29 July 2014

Revised: 7 November 2014 - Accepted: 16 November 2014 - Published: 22 December 2014

\begin{abstract}
Wet deposition is the dominant mechanism for removing black carbon (BC) from the atmosphere and is key in determining its atmospheric lifetime, vertical gradient and global transport. Despite the importance of $\mathrm{BC}$ in the climate system, especially in terms of its ability to modulate the radiative energy budget, there are few quantitative case studies of wet removal in ambient environments. We present a case study of $\mathrm{BC}$ wet removal by examining aerosol size distributions and $\mathrm{BC}$ coating properties sampled in three Canadian boreal biomass burning plumes, one of which passed through a precipitating cloud. This depleted the majority of the plume's BC mass, and the largest and most coated BCcontaining particles were found to be preferentially removed, suggesting that nucleation scavenging was likely the dominant mechanism. Calculated single-scattering albedo (SSA) showed little variation, as a large number of non-BC particles were also present in the precipitation-affected plume. The remaining $\mathrm{BC}$ cores were smaller than those observed in previous studies of $\mathrm{BC}$ in post-precipitation outflow over Asia, possibly due to the thick coating by hydrophilic compounds associated with the Canadian biomass burning particles. This study provides measurements of $\mathrm{BC}$ size, mixing state and removal efficiency to constrain model parameterisations of
\end{abstract}

$\mathrm{BC}$ wet removal in biomass burning regions, which will help to reduce uncertainty in radiative forcing calculations.

\section{Introduction}

Black carbon (BC) is the dominant absorbing aerosol in the atmosphere and is an important, ubiquitous climate-warming agent (Ramanathan and Carmichael, 2008; Chung et al., 2012; Bond et al., 2013). The optical properties of BC affect the single-scattering albedo (SSA) of an aerosol layer, which determines the sign of its radiative forcing (Haywood and Shine, 1995). Important uncertainties remain regarding global and local emissions of $\mathrm{BC}$, as well as its chemical processing, lifetime in the atmosphere and optical properties. Observations are required to further constrain and/or validate model parameterisations surrounding $\mathrm{BC}$ processes in the atmosphere. Open biomass burning (BB) is the largest source category of $\mathrm{BC}$, responsible for $\sim 40 \%$ of total emissions in the year 2000 (Bond et al., 2013), and the size distribution and mixing state of $\mathrm{BC}$ from this source are known to exhibit systematic differences to fossil fuel emissions (Kondo et al., 2011; Sahu et al., 2012). 
Modelling studies suggest wet deposition is the dominant mechanism for BC's removal from the atmosphere (Textor et al., 2006) and consequently determines its lifetime and atmospheric burden to first order. As convection is often accompanied by precipitation, this also affects vertical profiles of number and mass concentration, which are important for determining radiative forcing (Samset et al., 2013). Such profiles are often poorly represented by models (Koch et al., 2009) as calculated removal rates are sensitive to the microphysical schemes used (Textor et al., 2006; Croft et al., 2010; Vignati et al., 2010).

In climate models, complex aerosol-cloud interactions must be simplified to reduce computing requirements, and many microphysical processes are sub-grid in both space and time. In-cloud scavenging occurs in two stages: aerosol activation to form cloud droplets, and removal of droplets by precipitation. Cloud droplet number concentration may be calculated based on empirical relations with updraft velocity and aerosol number concentration (Lohmann et al., 2007). Alternatively, many models use parameterisations designed to emulate size- and composition-based Köhler theory and the competition for water vapour between activated aerosols growing to cloud droplets (Ghan et al., 2011). Precipitation is determined by calculating autoconversion rates (the rates at which cloud water is converted to precipitation) which are tuned to simulate detailed microphysical schemes (Lin et al., 1983; Liu and Daum, 2004). Below-cloud scavenging is calculated by multiplying the precipitation rate by a scavenging coefficient, which may be size-resolved, and again may be calculated empirically or based on theoretical considerations (Wang et al., 2010). Some models treat explicit sizeresolved, cloud liquid, ice and mixed-phase microphysics (e.g. Jacobson, 2003), and this can generate better agreement with measured vertical profiles. Observations (particularly of size distribution, hygroscopicity and mixing state) are needed to constrain both types of wet removal scheme (Koch et al., 2011). Explicit microphysical models are also used to investigate smaller-scale phenomena (such as cloud microphysics, cloud-aerosol interactions and air quality), and ambient measurements are similarly required for constraint and comparison.

Fresh BC is generally considered hydrophobic, though it may act as a cloud condensation nucleus (CCN) in liquid cloud if subsequently coated with hydrophilic material (Khalizov et al., 2009; Liu et al., 2013). In biomass burning plumes this coating is thought to occur in the first few hours after emission (Abel, 2003; Akagi et al., 2012), and coatings are generally thicker than in fossil fuel emissions (Kondo et al., 2011; Sahu et al., 2012). BB emissions can be efficient CCN (Lathem et al., 2013) and can also act as ice nuclei (IN) (Petters et al., 2009), though different chemical species in BB emissions may be more effective than others. Several recent studies have suggested that non-nucleation scavenging (i.e. impaction) mechanisms may be more effective for $\mathrm{BC}$ removal, both in mixed-phase (Twohy et al., 2010) and ice clouds (Stith et al., 2011; Baumgardner et al., 2008).

The different scavenging mechanisms exhibit different size- and composition-dependent efficiencies. In liquid cloud, BC generally requires a soluble coating to activate, and larger particles are generally more effective CCN (Dusek et al., 2006). For all primary ice nucleation modes, larger particles are also generally more efficient IN (Hoose and Möhler, 2012); however soluble coatings have been shown to inhibit BC ice nucleation (Koehler et al., 2009). Falling ice and raindrops may scavenge coarse-mode particles and liquid droplets, and hence remove particles that have already activated (Miller and Wang, 1991; Seinfeld and Pandis, 1998; Croft et al., 2009). This type of scavenging is also more efficient for Aitken mode aerosols. For typical BC size distributions, which span the Aitken and accumulation modes, impaction scavenging therefore favours smaller BC, whereas nucleation scavenging favours larger BC (Jacobson, 2003).

Oshima et al. (2012) calculated removal rates of dieseldominated $\mathrm{BC}$ by liquid clouds in convective air masses over the Yellow and East China seas. By comparing BC / CO ratios in different air parcels, they calculated the transmission efficiency of $\mathrm{BC}\left(\mathrm{TE}_{\mathrm{BC}}\right)$, the fraction of $\mathrm{BC}$ not removed by precipitation. Moteki et al. (2012) showed that larger BC particles, which also had more coating material, were more efficiently removed during this process, meaning they must have been scavenged by nucleation. For air masses in which the most $\mathrm{BC}$ was removed $\left(\mathrm{TE}_{\mathrm{BC}}<0.3\right)$ the remaining $\mathrm{BC}$ core size distribution was similar to that seen by Schwarz et al. (2010b) in pristine conditions in the remote Pacific, suggesting a fraction of $\mathrm{BC}$ is not removed by wet processes and is able to travel long distances. In this paper, we present a case study of size-dependent wet removal of biomass burning BC, which may behave differently to diesel-dominated $\mathrm{BC}$ due to its contrasting microphysical properties. Firstly, we present an overview of the experiment, and use back trajectories and weather satellite data to identify three plumes from Canadian boreal fires in the same region, one of which had passed through a region of a precipitating cloud. Franklin et al. (2014) recently highlighted aerosol depletion in similar plumes using remote sensing measurements, but they were unable to determine the mechanism or measure the properties of any particles remaining in the plume. We examine the aerosol size distributions and $\mathrm{BC}$ coating properties using in situ measurements sampled in the three plumes to determine the most likely removal mechanism and consider the effect this has on optical properties.

\section{Experimental}

\subsection{BORTAS-B}

BORTAS-B was the second phase of the BORTAS (Quantifying the impact of BOReal forest fires on Tropospheric ox- 
idants over the Atlantic using Aircraft and Satellites) project (Palmer et al., 2013) and took place over eastern Canada and the North Atlantic during July-August 2011. The project aimed to study the chemistry of biomass burning plumes using a combination of airborne, ground and remote sensing measurements. This paper uses airborne aerosol measurements made aboard the UK BAe-146-301 Atmospheric Research Aircraft (ARA) and focuses on a single flight (B622) on 20 July 2011. The flight track for B622 is shown in Fig. 1. The ARA took off from Halifax Stanfield International Airport at 14:56 UTC and flew a series of sawtooth and straight-and-level runs on a generally east-west axis, before landing at Québec City Jean Lesage International Airport at 19:11 UTC.

\subsection{Instrumentation}

\subsubsection{The single-particle soot photometer}

The single-particle soot photometer (SP2, Droplet Measurement Technologies, Boulder, CO, USA) uses laserinduced incandescence to measure refractory black carbon (rBC; hereafter referred to as BC) on a single-particle basis (Schwarz et al., 2006). Particles are drawn through a highintensity $1064 \mathrm{~nm} \mathrm{Nd:YAG} \mathrm{laser} \mathrm{which} \mathrm{heats} \mathrm{BC-containing}$ particles to incandescence. The incandescent light is detected by two photomultiplier tubes (PMTs), one fitted with a narrowband filter to determine incandescence temperature. During BORTAS these were run at different gain settings to expand the dynamic range of the instrument. The signal these two PMTs detect is proportional to the mass of refractory black carbon present in the particle, regardless of mixing state (Slowik et al., 2007; Moteki and Kondo, 2007), and converted to mass-equivalent core diameter $\left(D_{\mathrm{C}}\right)$ using a density of $1.8 \mathrm{~g} \mathrm{~cm}^{-3}$. The broadband PMT (measuring particles $60 \leq D_{\mathrm{C}} \leq 275 \mathrm{~nm}$ ) was calibrated using several sizes of monodisperse Aquadag (Henkel Corporation, Bay Point, CA, USA), with particle mass calculated using the massmobility relationship reported by Gysel et al. (2011). This was then corrected for the difference in the response of the instrument compared to atmospheric BC (Baumgardner et al., 2012; Laborde et al., 2012b). The narrowband PMT (measuring $90 \leq D_{\mathrm{C}} \leq 550 \mathrm{~nm}$ ) was then cross-calibrated to the broadband in the overlap region. The instrument was run with sufficient laser power to ensure $100 \%$ detection efficiency for BC particles $\geq 1 \mathrm{fg}$ (femtogram) (Schwarz et al., 2010a). In plumes, the statistical uncertainty in $\mathrm{BC}$ mass concentration was typically $\sim 10 \%$ for an averaging time of $10 \mathrm{~s}$, and accuracy within $20 \%$ due to possible differences between the instrumental response to biomass burning $\mathrm{BC}$ and the calibrant (Laborde et al., 2012a).

The instrumental setup of the SP2 on the ARA was described by McMeeking et al. (2010) and is briefly summarised here. The SP2 sampled through a $1 / 4$ in. stainlesssteel tube connected to a modified Rosemount inlet (Foltescu

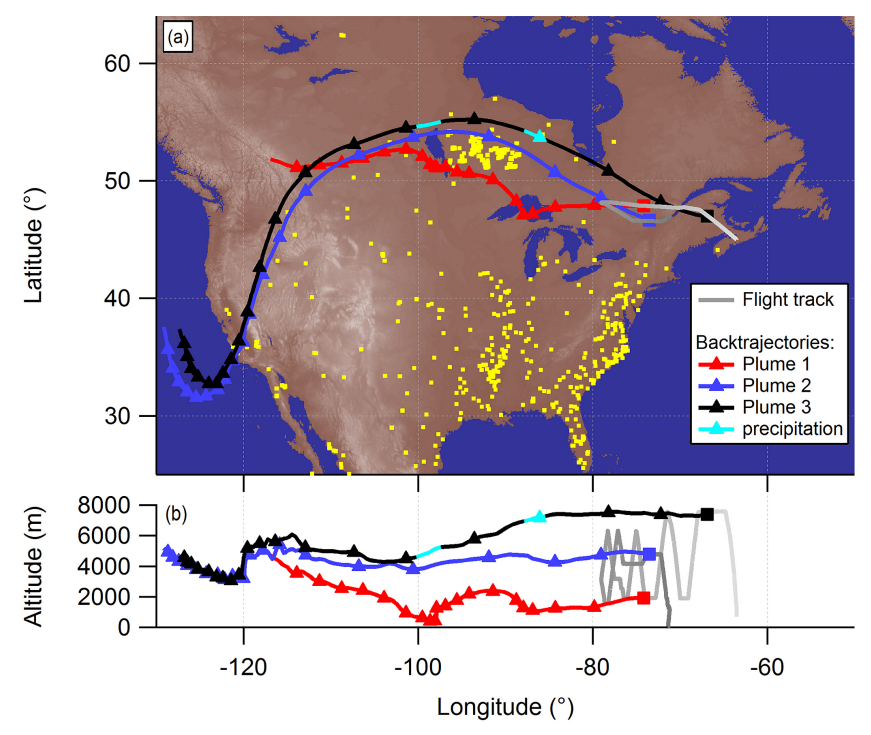

Figure 1. Five-day HYSPLIT back trajectories, starting at the time and location sampled (the square markers) and with triangular markers every $6 \mathrm{~h}$. Parts (a) and (b) show the horizontal and vertical tracks respectively. The aqua-coloured parts of the trajectories are regions with HYSPLIT precipitation, and the yellow dots show MODIS fire data between 18 and 20 July 2011. The grey line shows the flight track, starting from light grey and ending in dark grey.

et al., 1995). Though recent results have shown that Rosemount inlets can enhance aerosol measurements at larger diameters and higher densities, the vast majority of $\mathrm{BC}$ mass is present in particles $<600 \mathrm{~nm}$, where the efficiency is close to unity at densities typical of biomass burning emissions (Trembath et al., 2012). Losses between the inlet and the SP2 were minimised using a bypass flow of $1 \mathrm{~L} \mathrm{~min}^{-1}$, and this also reduced the residence time in the inlet.

The SP2 is also capable of measuring light-scattering particles (LSPs, particles that do not contain BC) and the coating properties of BC-containing particles. Two avalanche photodiodes (APDs) detect scattered light at $1064 \mathrm{~nm}$, and the detected signal is proportional to the scattering cross section of the particle. One APD is position-sensitive, and this provides a measure of the position of the particle in the laser (Gao et al., 2007). This allows calculation of the fractional laser power at the edge of the beam, as the laser has a Gaussian profile when configured correctly. Leading-edge-only (LEO) fitting is then used to calculate the scattering cross section of the particle before it begins to evaporate. In this work we considered the leading edge as data from the baseline up to $5 \%$ of the maximum laser intensity.

Mie core/shell modelling is then used to infer the coated particle diameter $\left(D_{\mathrm{P}}\right)$, and hence coating thickness, though this is dependent on the assumed core density and the refractive index of the $\mathrm{BC}$ core and coating (Taylor et al., 2014). In this analysis we assumed a BC core density of $1.8 \mathrm{~g} \mathrm{~cm}^{-3}$ (Bond and Bergstrom, 2006) and core refractive 
index $n_{\mathrm{C}}=(2.26-1.26 i)$ (Moteki et al., 2010). These parameters were shown by Taylor et al. (2014) to be the most appropriate for use with fossil fuel BC, by comparing Mie calculations to the scattering by thermodenuded particles. As a similar analysis of biomass burning emissions has not been performed, we used these parameters on the assumption that the core properties of fossil fuel and biomass burning BC are broadly similar. For the shell refractive index, we have assumed a value of $n_{\mathrm{S}}=(1.5+0 i)$ (Reid et al., 2005a).

\subsubsection{Aerosol mass spectrometer}

Nonrefractory submicron aerosol mass concentration was measured with a compact time-of-flight aerosol mass spectrometer (AMS, Aerodyne Research Inc, Billerica, MA, USA) (Drewnick et al., 2005; Canagaratna et al., 2007). The AMS reports organic aerosol (OA), sulfate, nitrate, ammonium and chloride mass concentrations, though in this analysis we only consider the OA concentrations. The operation of the AMS on the ARA has been described previously (Crosier et al., 2007; Morgan et al., 2009). The AMS was connected to a Rosemount inlet, and the aerosol flow is considered dry due to ram heating and the increase in temperature as the sample line passes into the cabin.

Data were processed as described by Morgan et al. (2010), using a collection efficiency of 0.5 . Unfortunately, after landing on B622 the aircraft lost power, and the AMS had to be shut down before an ionisation efficiency (IE) calibration could be performed. For B622 the calibration for the subsequent flight (B623) was applied, which may have introduced a systematic error in the AMS data. As an estimate of the size of this error, for the seven nitrate calibrations performed after B622, the standard deviation of the IE/airbeam was $13 \%$ of the mean. The calibrations before this were discarded because of a faulty power supply module in the AMS, which was replaced before B622. Also, in this case study the AMS data are only used to monitor relative changes in the $\mathrm{OA} / \mathrm{CO}$ ratio, so this increased uncertainty does not affect the analysis method or conclusions.

\subsubsection{Scanning mobility particle sizer}

A custom-made scanning mobility particle sizer (SMPS) system, sampling from the same inlet as the AMS, measured distributions of particle mobility diameter $\left(D_{\mathrm{mob}}\right)$ divided into 28 logarithmically spaced bins in the range $20-350 \mathrm{~nm}$. A custom-built low-pressure water-based condensation particle counter (WCPC model 3786-LP, Aerosol Dynamics, Berkeley, CA, USA/Quant Technologies, Blaine, MN, USA) was connected to a TSI 3081 differential mobility analyser (DMA). The WCPC drew $0.6 \mathrm{~L} \mathrm{~min}^{-1}$, half of which was used as the sample flow, and the DMA sheath flow was $6 \mathrm{~L} \min ^{-1}$. The data were inverted using routines developed by Zhou (2001), over a $30 \mathrm{~s}$ averaging time.

\subsubsection{Supporting measurements}

The aerosol light-scattering coefficient $\left(B_{\mathrm{Sca}}\right)$ was measured using an integrating nephelometer (TSI 3563, St. Paul, MN, USA). Here we only consider the scattering measurement at $550 \mathrm{~nm}$, though data from the instrument's other two wavelengths were used to correct for truncation and the nonLambertian light source (Anderson and Ogren, 1998). Relative humidity $(\mathrm{RH})$ measured in the nephelometer remained below $40 \%$, so no scattering enhancements due to swollen aerosol are expected (Magi, 2003). CO was measured by vacuum-UV resonance fluorescence, with accuracy of $\pm 3 \%$ and precision of $1 \mathrm{ppb}$ at $1 \mathrm{~Hz}$ (Gerbig et al., 1999). $\mathrm{CH}_{3} \mathrm{CN}$ (acetonitrile) was measured with a proton-transfer reaction mass spectrometer (PTR-MS) (Murphy et al., 2010) and HCN (hydrogen cyanide) with a chemical-ionisation mass spectrometer (CIMS) (Le Breton et al., 2013).

\subsection{Data analysis and plume identification}

The SP2 and instruments listed in Sect. 2.2.4 record data at $1 \mathrm{~Hz}$ and were averaged to $10 \mathrm{~s}$. The AMS records data every $8-9 \mathrm{~s}$, and so, for comparison, $\mathrm{CO}$ was also averaged to the AMS time series. SMPS scans were averaged over the relevant in-plume periods. All aerosol measurements were corrected to standard temperature $(273.15 \mathrm{~K})$ and pressure $(1013.25 \mathrm{hPa})$.

We identified three distinct plumes from B622 which were sampled during straight-and-level runs, flying at fixed heading and altitude. The times and locations of the plumes are listed in Table S1 in the Supplement. These plumes were selected as each plume had a large range of enhanced $\mathrm{CO}$ concentration above the regional background and good correlation between $\mathrm{CO}$ and $\mathrm{CH}_{3} \mathrm{CN}$, which are commonly used biomass burning tracers. Out-of-plume data were excluded using the thresholds defined by Palmer et al. (2013); only data with $\mathrm{CH}_{3} \mathrm{CN} \geq 150$ ppt, $\mathrm{CO} \geq 148 \mathrm{ppb}$ and $\mathrm{HCN}$ $\geq 122$ ppt were considered to be within a plume (see O'Shea et al. (2013) for a further discussion of the BORTAS airborne chemical climatology). These thresholds were determined from the 99th percentile measured in background air on flight B625 on 24 July 2011, on which no biomass burning plumes were detected (Palmer et al., 2013).

\subsection{Back trajectories and meteorology}

By examining Lagrangian back trajectories along with fire location, meteorological fields and satellite data, we can place each plume into the context of its air mass history. Fiveday back trajectories were calculated using the Hybrid Single Particle Lagrangian Integrated Trajectory Model (HYSPLIT) (Draxler and Hess, 1998), and are shown in Fig. 1. The trajectories were initialised using representative times and co-ordinates from the centre of each plume (defined as the mid-point of each straight-and-level run). The HYS- 
PLIT model was driven with full vertical dynamics using 3-hourly NCEP (National Centers for Environmental Prediction) GDAS (Global Data Assimilation System) reanalysis fields on a $1^{\circ}$ global grid and 23 model (sigma) levels. A comparison with O'Shea et al. (2013, Fig. 6c), who performed back trajectories along the entire B622 flight track, shows that these trajectories are representative of the air mass history at these altitudes.

Moderate-Resolution Imaging Spectrometer (MODIS) fire counts (Giglio et al., 2003) for 18-20 July are also shown in Fig. 1, though this only shows fires that were not masked by cloud. The trajectories for all three plumes are seen to have passed over a large region of forest fires in northwest Ontario, to the southwest of Hudson Bay and east of Lake Winnipeg. Plumes 2 and 3 were sampled approximately $\sim 1$ day after passing over the fires, while Plume 1 was sampled after $\sim 2$ days. The meteorology data used to calculate the HYSPLIT back trajectories do not take account of likely pyroconvection from the fires. Therefore the smoke plumes are expected to have formed a vertical emission profile, which would be expected to join the trajectories at the altitudes shown in Fig. 1. It is therefore not possible to identify a particular fire as the source of a plume, but all three plumes are clearly observed to have passed over the same region of fires.

The back trajectory from Plume 3 calculated precipitation from 11:30 to 13:00 and from 21:00 to 22:30 UTC on July 192011 (approximately 27 and $18 \mathrm{~h}$ before sampling respectively), as indicated by the aqua-coloured regions in Fig. 1. The HYSPLIT precipitation rates are extracted from the meteorological reanalysis data. Figure 2 shows cloud data measured by the Geostationary Operational Environmental Satellite (GOES) during these two time periods and highlights the region where the three back trajectories were at these times. The trajectories for Plumes 1 and 2 clearly avoided regions of deep convective cloud, though Plume 1 was below cloud at 13:00-14:45 UTC. During both periods that showed precipitation, the trajectory for Plume 3 was co-located with a cloud system associated with a warm front, with effective cloud height in excess of $10 \mathrm{~km}$ and cloud depth up to $7 \mathrm{~km}$, indicative of deep convection, potentially enhanced by pyroconvection at that time. The retrieved cloud-top phase was ice, but as Plume 3's trajectory passed through the cloud at an altitude of $5-7 \mathrm{~km}$, we are unable to speculate on what phase of cloud the plume passed through. The retrieved ice water path (IWP) gives a qualitative indication of precipitation in these clouds. In Fig. 2, it is clear that the frontal cloud that Plume 3 passed through not only was $7 \mathrm{~km}$ deep but also has a core of IWP in excess of $1000 \mathrm{~g} \mathrm{~m}^{-2}$, suggesting that this deep convective (frontal) cloud was actively precipitating (Lin and Rossow, 1997).

Although HYSPLIT can effectively model vertical transport in synoptic-scale features such as fronts, it (as well as any Lagrangian model driven by coarse-resolution meteorological fields) cannot capture convection (and hence transport) in isolated convective systems (Stohl et al., 2001). The possibility of unresolved deep convective systems, which could also reduce the coherence of the trajectories, may decrease confidence in the exact trajectory of Plume 3 , but only for the part of that trajectory before passage through the frontal region. The portion of the trajectory tracing Plume 3 back to a precipitating region of the front, and to the region of fires, is therefore still expected to be robust.

Uncertainty in the calculated trajectories and the coarse resolution of the meteorology data used by HYSPLIT mean that the calculated precipitation rates cannot necessarily be considered accurate, but they do highlight the presence of precipitating clouds in the area near where the plume passed. The GOES data confirm the presence of a deep convective cloud in this region that was likely to have been precipitating. In the next section we examine aerosol tracer ratios and demonstrate that most of the aerosol in this plume must have been removed by precipitation.

\section{Results}

\subsection{Chemical tracer ratios}

Figure 3 shows the $\mathrm{BC} / \mathrm{CO}, \mathrm{OA} / \mathrm{CO}$ and $\mathrm{BC} / B_{\text {Sca }}$ ratios measured in the three plumes described in Sect. 2.3. The gradients of $\mathrm{BC} / \mathrm{CO}$ and $\mathrm{OA} / \mathrm{CO}$ are listed in Table 1, while the $\mathrm{BC} / B_{\text {Sca }}$ gradients are listed in Table 3 and discussed later in Sect. 3.3. These ratios are a product of the initial emission ratios and physical processes between emission and measurement.

Both $\mathrm{BC}$ and OA may be affected by wet removal, and OA / CO may increase or decrease due to evaporation or condensation of OA (Donahue et al., 2011). While there was some variation between Plumes 1 and 2, which did not show evidence of precipitation, this is not unexpected. Several studies have demonstrated the dependence of aerosol emission ratios on combustion conditions (e.g. McMeeking et al., 2009; Kondo et al., 2011), as BC is more associated with flaming combustion and OA with smouldering. Although $\mathrm{CO}_{2}$ data were available for the campaign, which can be used in conjunction with $\mathrm{CO}$ to characterise combustion efficiency (Ward and Radke, 1993), we did not consider this calculation robust as the variation in $\mathrm{CO}_{2}$ background was greater than the excess in the plumes, meaning the derived slopes $\left(\partial \mathrm{CO} / \partial \mathrm{CO}_{2}\right)$ may be misleading (Yokelson et al., 2013). This issue did not affect the aerosol or CO measurements as the background variations were small compared to the excess levels in the plumes.

Table 1 presents a comparison of tracer ratios with several other studies and emission inventory values. This is not intended to be a comprehensive review of all previous measurements, but to demonstrate the range of values typically observed. BC / CO in Plume 3 was significantly below the other reported values that were unaffected by precipitation, and it was most similar to those measured during the Inter- 

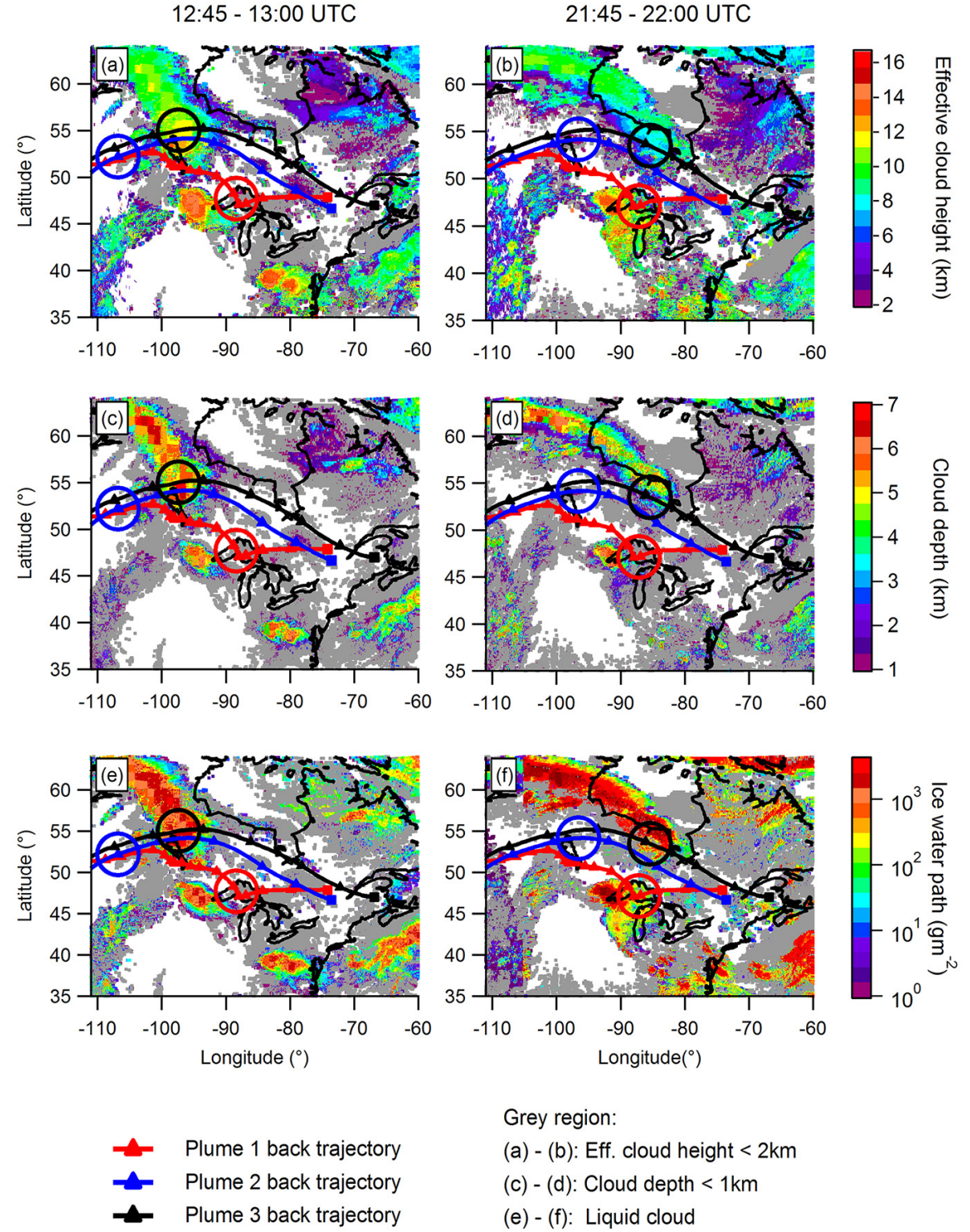

Grey region:
(a) - (b): Eff. cloud height $<2 \mathrm{~km}$
(c) - (d): Cloud depth $<1 \mathrm{~km}$
(e) - (f): Liquid cloud

Figure 2. Cloud data from the GOES satellite from 19 July 2011. The retrievals are from the periods when the meteorology data in the back trajectory for Plume 3 showed precipitation. Parts (a) and (b) show effective cloud height, (c) and (d) show cloud depth (calculated as the difference between effective cloud height and cloud bottom) and parts (e) and (f) show ice water path. The back trajectories are the same as those shown in Fig. 1, and the circles show the locations of the back trajectories at the time of the GOES retrievals.

national Consortium for Atmospheric Research on Transport and Transformation (ICARTT) in Alaskan/Canadian boreal plumes that were also affected by precipitation (Val Martín et al., 2006). BC / CO was an order of magnitude lower in Plume 3 than the average for plumes unaffected by precipitation. While the poor correlation between $\mathrm{OA}$ and $\mathrm{CO}$ in Plume 3 means this ratio cannot be considered reliably accurate, it is clear that it was also significantly below all other measurements listed. By comparing to literature values and the other plumes in this study, it is clear that both $\mathrm{BC} / \mathrm{CO}$ and $\mathrm{OA} / \mathrm{CO}$ in Plume 3 were largely the result of the wet removal itself, rather than the initial combustion conditions.

Figure $3 \mathrm{c}$ shows the correlations between $\mathrm{BC}$ mass concentration and $B_{\text {Sca }}$ measured by the nephelometer. For Plume 3, this provides a better comparison than $\mathrm{BC} / \mathrm{OA}$, as the AMS signal / noise was low at high altitude. There was excellent correlation in all three plumes, meaning there was no significant difference in the removal efficiencies of the bulk of $\mathrm{BC}$ and nonrefractory mass. Comparing the slopes in Fig. 3a and b, it is clear that the majority of $\mathrm{BC}$ and organics were removed in Plume 3. 
Table 1. Ratios of BC / CO and OA / CO from this study and several previous measurements. The ratios from this study were calculated from Fig. 3, and listed errors are the fit errors.

\begin{tabular}{llrrl}
\hline Project/plume & Description & $\begin{array}{r}\mathrm{BC} / \mathrm{CO} \\
\left(\mu \mathrm{g} \mathrm{sm}^{-3} / \mathrm{ppmv}\right)\end{array}$ & $\begin{array}{r}\text { OA } / \mathrm{CO} \\
\left(\mu \mathrm{g} \mathrm{sm}^{-3} / \mathrm{ppmv}\right)\end{array}$ & Reference \\
\hline Plume 1 & Canadian boreal forest & $3.28 \pm 0.06$ & $174 \pm 5$ & This study \\
Plume 2 & Canadian boreal forest & $5.4 \pm 0.5$ & $78 \pm 5$ & This study \\
Plume 3 & Canadian boreal forest & $0.61 \pm 0.04$ & $0.4 \pm 0.3$ & This study \\
ARCTAS & Asian boreal forest & $9 \pm 5$ & $110^{\mathrm{a}}$ & Hecobian et al. (2010); Kondo et al. (2011) \\
ARCTAS & Canadian boreal forest & $2 \pm 2$ & 120 & Hecobian et al. (2010); Kondo et al. (2011) \\
ARCTAS & Californian boreal forest & $3.4 \pm 1.4$ & 100 & Hecobian et al. (2010); Kondo et al. (2011) \\
TexAQS & Unknown BB & $9 \pm 2$ & - & Schwarz et al. (2008) \\
ICARTT non-precip. & N. American boreal forest & $2.5-8.4$ & $59.1-188.4^{\mathrm{b}}$ & Sullivan et al. (2006); Val Martín et al. (2006) \\
ICARTT precip. & N. American boreal forest & $0.47-2.2$ & - & Sullivan et al. (2006); Val Martín et al. (2006) \\
Prescribed burn & Large shrubs & 18 & 82 & Pratt et al. (2011) \\
Emission inventory & Extratropical forest & $6.5 \pm 3.2$ & $150-170^{\mathrm{b}}$ & Andreae and Merlet (2001) \\
\hline
\end{tabular}

${ }^{\mathrm{a}}$ Estimated from Siberian and mixed Siberian + Asian BB. ${ }^{\mathrm{b}}$ Assuming OM : OC ratio of 1.5 (Reid et al., 2005b).

\subsection{Aerosol size and coating distributions}

In this section we examine the effects of the precipitation event on particle size distributions. Biomass burning size distributions at source show a large amount of variation (Reid et al., 2005b). Additionally, aerosol concentrations in biomass burning plumes mean that coagulation can significantly affect the size distribution over timescales of hours (e.g. Capes et al., 2008). It is therefore not always possible to compare size distributions between different fires.

\subsubsection{Bulk aerosol size distributions}

Figure 4 shows SMPS size distributions for the three plumes in this case study. Plumes 1 and 2 had a count median diameter (CMD) of 196 and $194 \mathrm{~nm}$ respectively, whereas Plume 3 had a CMD of $101 \mathrm{~nm}$. The particles in Plumes 1 and 2 were larger than those reported for fresh Canadian boreal BB plumes during ARCTAS-B (Arctic Research of the Composition of the Troposphere from Aircraft and Satellite - summer; Lathem et al., 2013), due to a different source profile and/or coagulation. The similarity between Plumes 1 and 2 is likely as they were from the same set of fires and had similar transport times. We can therefore infer that, had Plume 3 not been affected by precipitation, it would likely have had a similar size distribution. As the particles in Plume 3 were much smaller than in Plumes 1 and 2, this suggests nucleation scavenging was the wet removal mechanism, as this process favours larger particles (Dusek et al., 2006). The remaining particles were probably interstitial in the cloud (i.e. not activated), and this is qualitatively consistent with the difference between cloud residual and interstitial size distributions seen previously (Allan et al., 2008).

OA comprised over $85 \%$ of the aerosol measured in Plumes 1 and 2. The fraction of OA mass measured in the AMS at $m / z 44\left(f_{44}\right)$ provides a measure of the oxygenation of the OA fraction ( $\mathrm{Ng}$ et al., 2010). The mean values of $f_{44}$ measured in Plumes 1 and 2 were 0.085 and 0.120 respectively, which are indicative of a reasonable degree of oxidation. Previous studies have shown that increased $f_{44}$ is qualitatively related to increased hygroscopicity (e.g. Duplissy et al., 2011), though this is to an extent system dependent. The $f_{44}$ in these plumes indicates the OA was likely hygroscopic and may act as a $\mathrm{CCN}$ at sufficient supersaturations. The mass of OA measured at $m / z 44$ in Plume 3 was not sufficient to make a robust calculation of $f_{44}$, so it is not possible to make a comparison.

\subsubsection{BC core size distributions}

Although coagulation can quickly affect bulk size distributions, BC-containing particles represent a small fraction of the total number concentration. Kondo et al. (2011) found little variation in $\mathrm{BC}$ core size distributions from Canadian biomass burning, meaning the effects of $\mathrm{BC}-\mathrm{BC}$ coagulation are likely to be minor over the timescale of 1-2 days. Figure 5 shows the $\mathrm{BC}$ core size distributions in the three plumes, and a comparison to literature values of CMD and mass-median core diameter (MMD) is presented in Table 2. The BC mass distributions of Plumes 1 and 2 were very similar, though there was a smaller mode in the number distribution for Plume 1, which may suggest some limited mixing with fossil fuel emissions in the boundary layer. This is unlikely to affect total $\mathrm{BC}$ mass as the mode is not clear in the mass distribution. The BC CMDs for Plumes 1 and 2 therefore show a difference of $\sim 10 \mathrm{~nm}$, whereas the MMDs were nearly identical.

The $\mathrm{BC}$ CMD is a more qualitative measurement than the MMD as it is more sensitive to the detection range of the instrument. The SP2 typically has good detection efficiency only for particles $\geq 1 \mathrm{fg}$, equivalent to $\sim 100 \mathrm{~nm}$ in diameter (Schwarz et al., 2010a). For smaller BC cores, the detection efficiency drops down to zero, though the rate at which this occurs depends on the laser power. Not only is it possible therefore that the $\mathrm{BC}$ CMD is sensitive to the instrumental setup of the SP2; it is also possible that the true CMD is too 

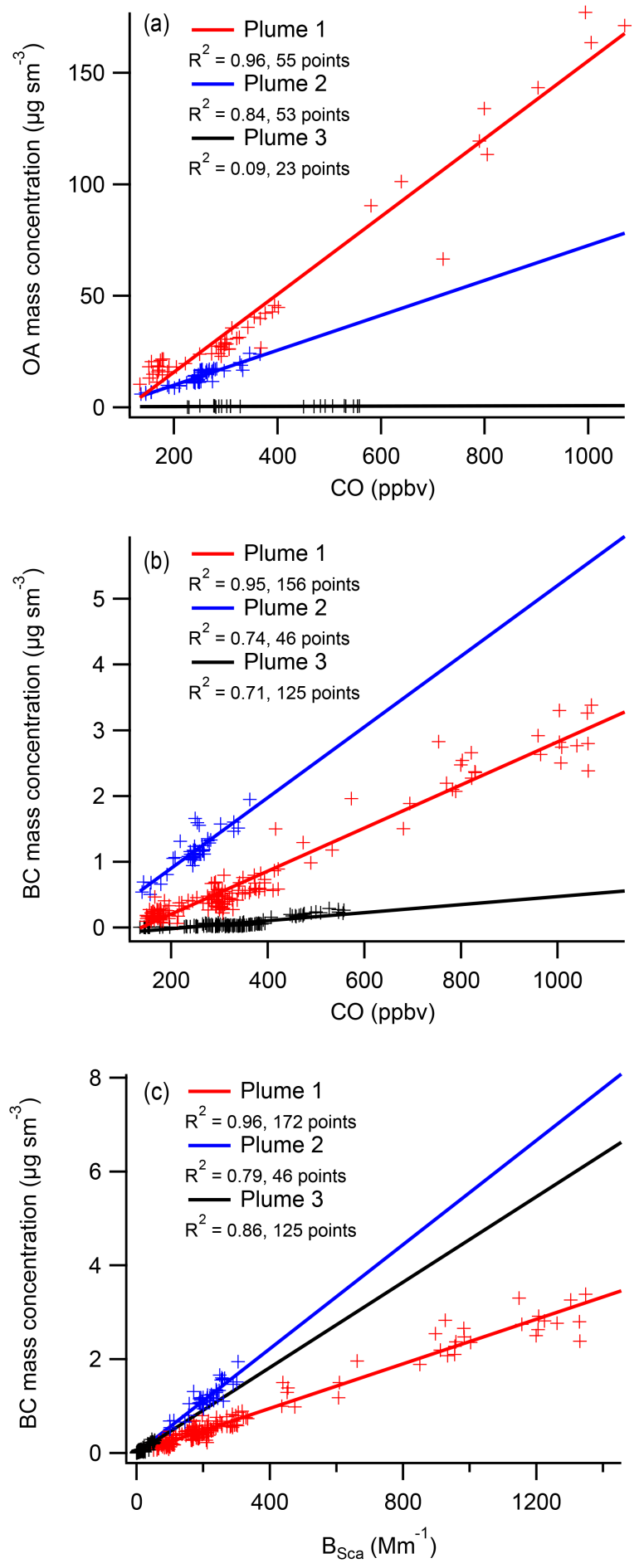

Figure 3. Correlations of (a) $\mathrm{OA} / \mathrm{CO}$, (b) $\mathrm{BC} / \mathrm{CO}$ and (c) $\mathrm{BC} / B_{\mathrm{Sca}}$ in the three plumes. The slopes (which were calculated by orthogonal distance regression) are listed in Table 1 for (a) and (b) and Table 3 for (c). The peak OA concentration in Plume 3 was $1.4 \mu \mathrm{g} \mathrm{sm}^{-3}$.

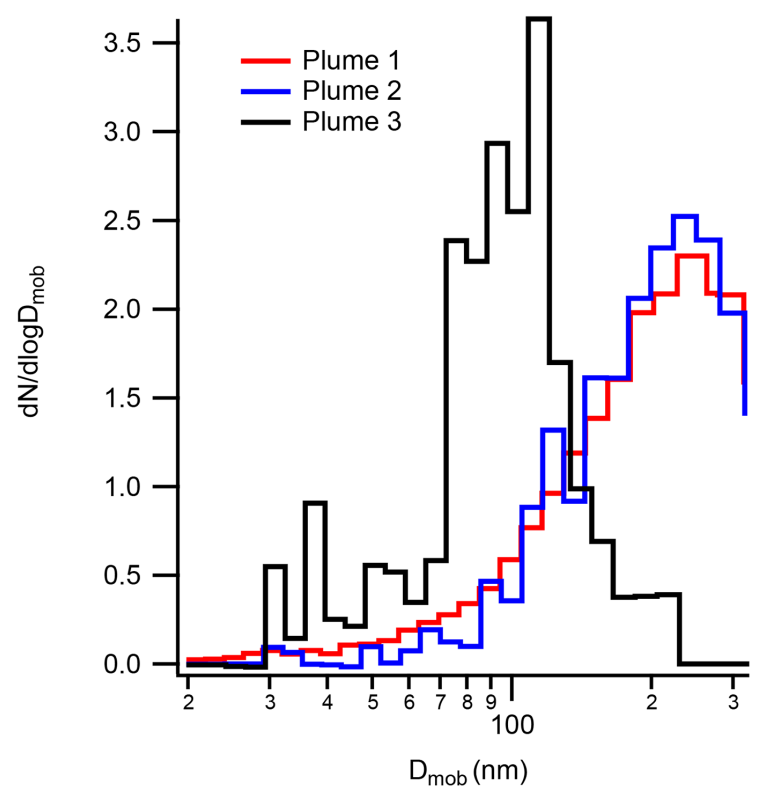

Figure 4. Average normalised bulk size distributions measured by the SMPS.

small to be detectable at all (e.g. Liggio et al., 2012). A significant fraction of the total $\mathrm{BC}$ number is $<1 \mathrm{fg}$, but as the smallest $\mathrm{BC}$ particles contribute little to $\mathrm{BC}$ mass, the MMD is well above the cut-off of the instrument. We therefore consider MMD a more robust variable to test for variation in $\mathrm{BC}$ size distribution.

The literature vales of BC MMD in Table 2 range from 194 to $214 \mathrm{~nm}$, and Plumes 1 and 2 fall within the lower end of this range. These also compare very well to Canadian plumes from ARCTAS, which were sampled close to emission (Kondo et al., 2011). Plume 3 shows a distribution skewed to smaller sizes, with MMD of $152 \mathrm{~nm}$, smaller even than measured in some fossil fuel emissions (Sahu et al., 2012). The similarity of the size dependence of wet removal between bulk aerosol and black carbon (shown in Figs. 4 and 5 respectively) suggests that $\mathrm{BC}$-containing particles were also removed by nucleation scavenging, rather than another mechanism. As Fig. 3 shows the vast majority of BC mass was removed in the plume, and Fig. 5 shows there was still a significant overlap in the size distributions, this shows that the majority of $\mathrm{BC}$ particles across most of the size distribution were removed by the precipitation event. In order to activate, $\mathrm{BC}$ requires coating by hydrophilic material (Zhang et al., 2008; Khalizov et al., 2009). We examine coatings measured by the SP2 in the next section.

\subsubsection{BC coating distributions}

$\mathrm{BC}$ coatings were calculated for $\mathrm{BC}$ particles in the range $130 \leq D_{\mathrm{C}} \leq 230 \mathrm{~nm}$. This range was determined using the method outlined by Taylor et al. (2014). Figure 6 shows the measured distributions of coating thickness, expressed in 

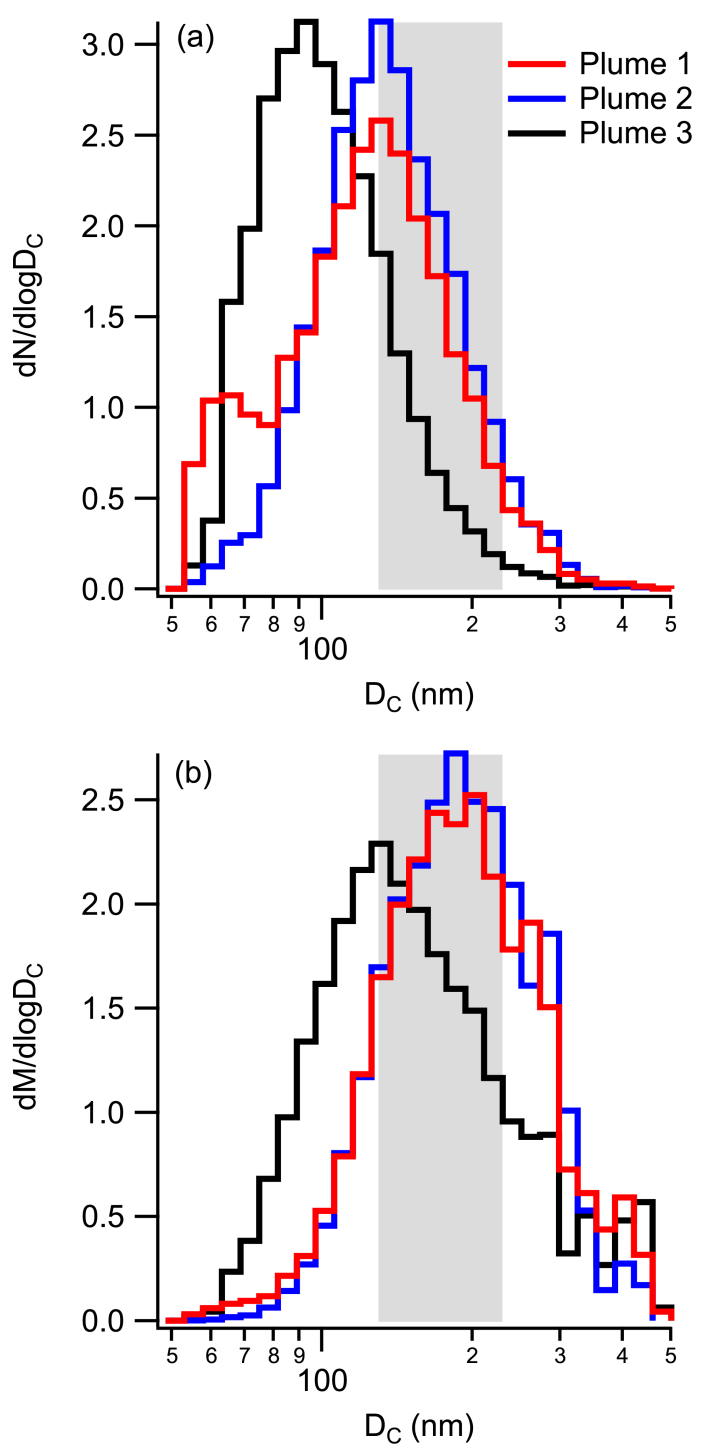

Figure 5. Normalised average BC core size distributions measured by the SP2 during the three plumes. Part (a) presents the number distribution, and part (b) the mass distribution. The discontinuity at $\sim 300 \mathrm{~nm}$ is due to saturation of the broadband detector and switching to the narrowband. The grey shaded regions show the range of core diameter used for calculating coating properties.

terms of shell/ core ratio and absolute coating thickness. In all three plumes, nearly all particles had measurable coatings. Plumes 1 and 2 had broadly similar distributions, with similar median shell / core ratios of 2.34 and 2.35 and absolute coating thicknesses of 110 and $107 \mathrm{~nm}$ respectively. Plume 2 had a slightly higher proportion of less-coated particles, probably due to mixing with a small amount of anthropogenic emissions in the boundary layer. However, this does not appear to have significantly affected the shape of the distribution, or the median values. Plume 3 had thinner coatings overall, with median shell / core ratio of 2.02 and absolute coating thickness of $79 \mathrm{~nm}$. This suggests that the more-coated particles were more effective $\mathrm{CCN}$ and hence were removed more efficiently, likely due to both the increased $D_{\mathrm{p}}$ and greater soluble content.

Figure 5 compares the $\mathrm{BC}$ mass and number distributions to the range of $\mathrm{BC}$ core diameters that was used for calculating coating properties, $130 \leq D_{\mathrm{C}} \leq 230 \mathrm{~nm}$. For Plumes 1 and 2 this range spans the mode of the mass distribution and is just above the mode of the number distribution, whereas for Plume 3 it borders the mode of the mass distribution and is above the mode of the number distribution. However, as this range is larger than the number mode in all three plumes, the median coating properties are weighted towards the lower end of this range. The range is not significantly far from the mass mode in Plume 3, and so it is likely representative of the bulk of $\mathrm{BC}$ mass in all three plumes.

\subsection{The effect of wet removal on optical properties}

Figure $3 \mathrm{c}$ shows correlations between BC mass loading and $B_{\text {Sca }}$, and the slopes are listed in Table 3. While there is over a factor of 2 spanning the slopes, this does not appear to be governed by the wet removal. The slopes for Plumes 1 and 2 show the greatest difference, meaning this is probably due to the initial combustion conditions and photochemical processing that occurred between emission and measurement, though Plume 1 has a possible minor contribution by mixing with other aerosols in the boundary layer. While the shift to smaller sizes will have reduced the per-particle scattering cross sections, it also reduced the average $\mathrm{BC}$ mass, and so this ratio was not as affected as the $\mathrm{BC} / \mathrm{CO}$ or $\mathrm{OA} / \mathrm{CO}$. As noted in Sect. 3.2.2, the majority of $\mathrm{BC}$ particles were removed by the precipitation event over most of the size range.

Table 3 also lists the mass absorption coefficient (MAC) for the three plumes, calculated at $550 \mathrm{~nm}$ using the SP2 data. This calculation is integrated over the entire measured $\mathrm{BC}$ size distribution. Though the coating properties were calculated using a BC core refractive index of $n_{\text {core }}=(2.26-$ $1.26 i)$ at $1064 \mathrm{~nm}$, this is not appropriate for use at visible wavelengths when using the Mie model (Taylor et al., 2015). We therefore used $n_{\text {core }}=(1.85-0.71 i)$, the central refractive index listed by Bond and Bergstrom (2006). A sensitivity analysis of this assumption is presented in Table $\mathrm{S} 2$. We also assumed that BC coatings and particles not associated with BC did not absorb. While this assumption may not hold at shorter wavelengths, brown carbon absorption at $550 \mathrm{~nm}$ is highly uncertain (McNaughton et al., 2011; Kirchstetter and Thatcher, 2012; Lack et al., 2012), and we are unable to constrain this using these observations. We are also unable to constrain any hygroscopic growth the particles may undergo in ambient humidities, and therefore all our calculations are performed under the dry $(<40 \%) \mathrm{RH}$ conditions of the sample line.

As the coating distributions were only measured in the range $130 \leq D_{\mathrm{C}} \leq 230 \mathrm{~nm}$, coatings at other core sizes must be inferred from this size range. Table 3 presents 
Table 2. BC core size distribution properties for the three plumes, and a comparison of literature values. $\sigma_{\text {geo }}$ refers to the geometric standard deviation. The ARCTAS values are averages of multiple fires sampled over North America.

\begin{tabular}{lrrrl}
\hline & $\begin{array}{r}\text { BC core } \\
\text { CMD }(\mathrm{nm})^{*}\end{array}$ & $\begin{array}{r}\text { BC core } \\
\text { MMD }(\mathrm{nm})^{*}\end{array}$ & $\begin{array}{r}\text { BC core } \\
\sigma_{\text {geo }}\end{array}$ & Reference \\
\hline Plume 1 & 128 & 196 & 1.49 & This study \\
Plume 2 & 137 & 194 & 1.38 & This study \\
Plume 3 & 100 & 152 & 1.37 & This study \\
ARCTAS Asian BB & 146 & 214 & 1.37 & Kondo et al. (2011) \\
ARCTAS Canadian BB & 141 & 194 & 1.32 & Kondo et al. (2011) \\
ARCTAS-CARB Californian BB & 146 & 200 & 1.33 & Sahu et al. (2012) \\
TexAQS BB & 140 & 210 & - & Schwarz et al. (2008) \\
CARB fossil fuel & 119 & 175 & 1.36 & Sahu et al. (2012) \\
\hline
\end{tabular}

* Literature values are corrected to $\mathrm{BC}$ core density of $1.8 \mathrm{~g} \mathrm{~cm}^{-3}$.

Table 3. BC optical properties (at $532 \mathrm{~nm}$ ) in the three plumes. BC / $\mathrm{B}_{\text {Sca }}$ ratios are the slopes from Fig. 3c, calculated using orthogonal distance regression fits with zero offset. The listed errors are the fit errors. MAC was calculated using the measured BC core size and coating distributions, integrated over the entire BC size distribution, assuming either a constant distribution of shell/core ratio or absolute coating thickness from Fig. 6 . The stated values were calculated using BC core and coating refractive indices $n_{\text {core }}=(1.85-0.71 i)$ and $n_{\text {coat }}=(1.50-0 i) . \mathrm{B}_{\mathrm{abs}} / \mathrm{CO}$ and errors are the standard deviation of the corresponding range in Table S2. SSA values were calculated by combining the calculated MAC with measured $\mathrm{BC} / \mathrm{CO}$ and $\mathrm{BC} / \mathrm{B}_{\text {Sca }}$.

\begin{tabular}{lccrc}
\hline & $\begin{array}{c}\text { Calculated MAC } \\
\left(\mathrm{m}^{2} \mathrm{~g}^{-1}\right)\end{array}$ & $\begin{array}{c}B_{\mathrm{abs}} / \mathrm{CO} \\
\left(\mathrm{Mm}^{-1} / \mathrm{ppmv}\right)\end{array}$ & $\begin{array}{r}\mathrm{BC} / B_{\mathrm{Sca}} \\
\left(\mu \mathrm{g} \mathrm{sm}^{-3} / \mathrm{Mm}^{-1}\right)\end{array}$ & SSA \\
\hline \multicolumn{5}{c}{ Using shell / core ratio distribution } \\
Plume 1 & $10.64 \pm 0.64$ & $34.9 \pm 0.6$ & $2.38 \pm 0.03$ & 0.975 \\
Plume 2 & $10.95 \pm 0.63$ & $59 \pm 5$ & $5.55 \pm 0.09$ & 0.943 \\
Plume 3 & $10.24 \pm 0.68$ & $6.2 \pm 0.4$ & $4.36 \pm 0.15$ & 0.957 \\
\hline \multicolumn{5}{c}{ Using coating thickness distribution } \\
Plume 1 & $9.10 \pm 0.53$ & $29.8 \pm 1.8$ & $2.38 \pm 0.03$ & 0.979 \\
Plume 2 & $9.27 \pm 0.55$ & $50 \pm 5$ & $5.55 \pm 0.09$ & 0.951 \\
Plume 3 & $8.79 \pm 0.55$ & $5.4 \pm 0.5$ & $4.36 \pm 0.15$ & 0.963 \\
\hline
\end{tabular}

MAC calculated assuming either a constant distribution of shell / core ratio or a constant distribution of absolute coating thickness, as shown in Fig. 6. A constant shell/core ratio distribution gives thicker absolute coatings to larger cores, whereas a constant absolute coating thickness distribution gives large shell / core ratios to smaller cores. The differences in calculated MAC between the two cases are 15-20\%. A more realistic treatment of the variation in $\mathrm{BC}$ coatings with core size would require detailed modelling of condensation and coagulation processes, and is not in the scope of this analysis.

For comparison, McNaughton et al. (2011) separated out the different contributions of brown carbon, mineral dust and $\mathrm{BC}$ in boreal $\mathrm{BB}$ plumes during ARCTAS/ARCPAC (Aerosol, Radiation, and Cloud Processes affecting Arctic Climate) and reported average MAC of BC of $9.5 \pm$ $0.6 \mathrm{~m}^{2} \mathrm{~g}^{-1}$ at $530 \mathrm{~nm}$. We note however that this was derived using a filter-based absorption measurement, which suffers from systematic errors that must be corrected empirically (Lack et al., 2008; Cappa et al., 2008). MAC calculated in
Plumes 1 and 2 using the absolute coating thickness distribution shows good agreement with this average, though absolute agreement using the shell/core ratio distribution is possible if using a smaller (real and imaginary) core refractive index (see Table S2). Additionally, Table 2 shows the BC core size distributions discussed here were smaller than those measured during ARCTAS, which would have increased MAC. The coatings measured here were also thicker than those reported during ARCTAS/ARCPAC by Kondo et al. (2011), which would also increase MAC, though these measurements are not absolutely comparable due to the different methods used (Taylor et al., 2014).

Regardless of which method was used to incorporate the coating distributions, the modelled MAC in the three plumes varies by $<10 \%$. This is in spite of clear differences in the core size and coating distributions between Plumes 1 and 2 and Plume 3. Figure 7 compares the BC core size distributions to the size-dependent MAC, calculated using the measured distribution of shell/core ratio for each plume. For a given core diameter, Plumes 1 and 2 have generally higher 

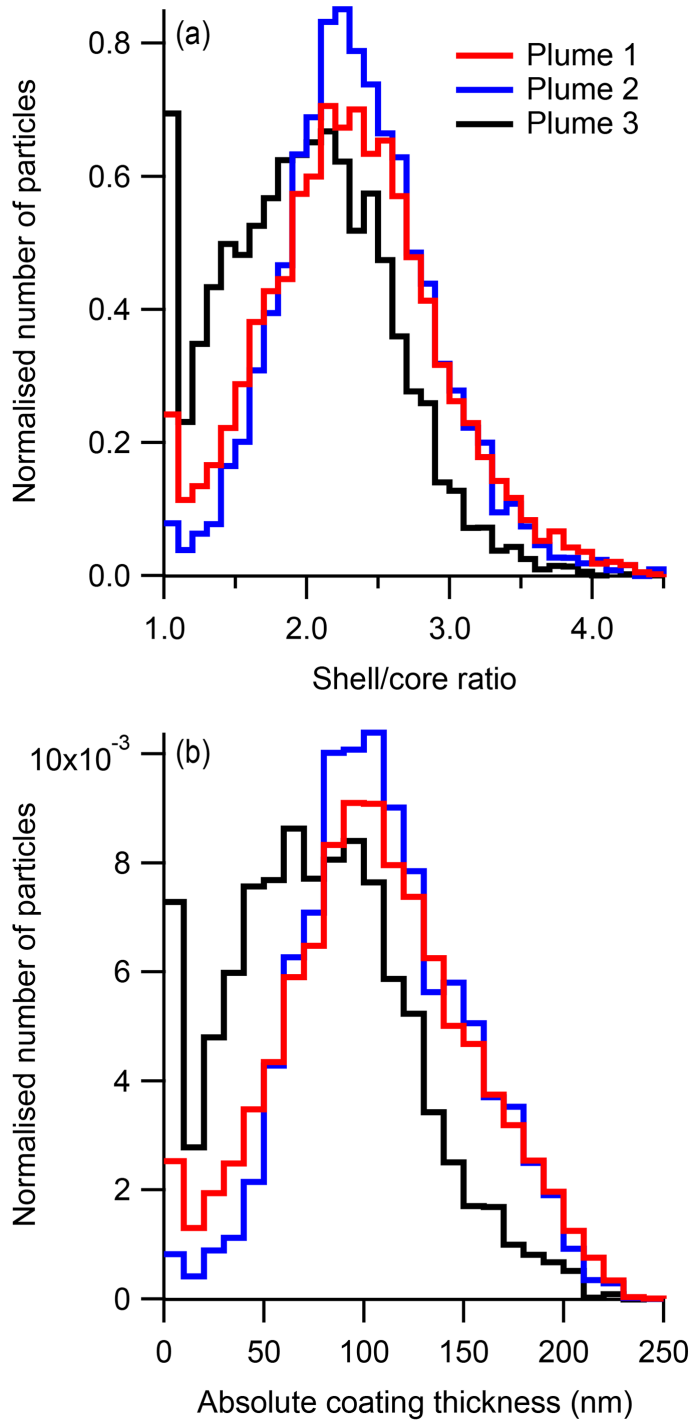

Figure 6. Distributions of coating thicknesses, measured by the $\mathrm{SP} 2$, expressed in terms of (a) shell/core ratio and (b) absolute coating thickness. The first bin $\left(D_{\mathrm{P}}=D_{\mathrm{C}}=1\right.$, uncoated particle) also contains all particles with measured scattering less than that predicted for an uncoated core (equivalent to $D_{\mathrm{P}}<D_{\mathrm{C}}$ ). Such particles are a result of random variations in the detected scattering; however as the result $D_{\mathrm{P}}<D_{\mathrm{C}}$ is nonphysical, they are assigned the nearest realistic value.

MAC than Plume 3, as they had thicker coatings. However, as the core size distribution in Plume 3 was smaller, this largely cancels out this change, and therefore the calculated MAC shows little variation between the plumes.

Multiplying the calculated MAC by the $\mathrm{BC} / \mathrm{CO}$ ratios in Table 1 gives $B_{\mathrm{Abs}} / \mathrm{CO}$, black carbon absorption per ppbv of $\mathrm{CO}$. While there is some variation between Plumes 1 and 2, Plume 3 is an order of magnitude lower, due to its lower $\mathrm{BC} / \mathrm{CO}$ ratio. As the MAC does not vary significantly between the plumes, $\mathrm{BC} / \mathrm{CO}$ was the controlling factor deter-

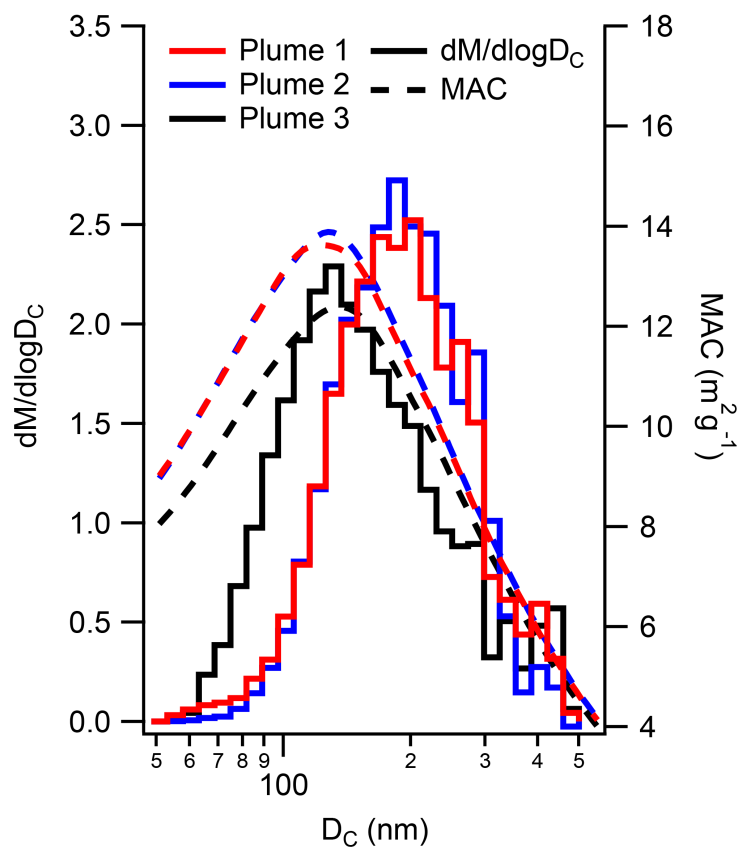

Figure 7. BC core size distributions measured by the SP2 and calculated size-dependent MAC for the three plumes, calculated using $n_{\text {core }}=(1.85-0.71 i)$ and assuming a constant distribution of shell / core ratio.

mining aerosol absorption in these plumes. Combining these values with the measured $\mathrm{BC} / B_{\mathrm{Sca}}$, one can calculate SSA using

$\mathrm{SSA}=\frac{1}{\left(1+\frac{B_{\mathrm{Abs}}}{B_{\mathrm{Sca}}}\right)}=\frac{1}{\left(1+\mathrm{MAC} \times \frac{\mathrm{BC}}{B_{\mathrm{Sca}}}\right)}$.

Calculated bulk SSAs are presented in Table 3. SSA was high in all plumes, even for aged smoke (Reid et al., 2005a), though this would be reduced slightly if absorption by brown carbon had been included. They also compare well to SSA measured in boreal BB plumes during ARCTAS/ARCPAC (McNaughton et al., 2011). Though there was some variation between the plumes, Plume 3 was the central value. This shows that wet removal had only a minor effect on SSA compared to the burn conditions and secondary condensation.

\section{Discussion}

Moteki et al. (2012) listed CMD for BC core size distributions in Asian outflow after different amounts of wet removal. In free troposphere outflow the CMD was $132 \mathrm{~nm}$ (corrected to a $\mathrm{BC}$ core density of $1.8 \mathrm{~g} \mathrm{~cm}^{-3}$ ) in air masses with transmission efficiency $\mathrm{TE}_{\mathrm{BC}}>80 \%$ and $100 \mathrm{~nm}$ for $\mathrm{TE}_{\mathrm{BC}}<30 \%$. While this shows excellent agreement with the CMDs measured in this analysis, the CMD is sensitive to the detection efficiency at the lower cut-off of the BC number distribution. 
Moteki et al. (2012) also listed $<m>$, the mean BC mass per BC-containing particle. Based on their fit data, this ranged from $5.87 \mathrm{fg}$ for $\mathrm{TE}_{\mathrm{BC}}=1$ and $2.74 \mathrm{fg}$ for $\mathrm{TE}_{\mathrm{BC}}=0$. For comparison, $<m>$ was $3.65 \mathrm{fg}, 4.17$ and $1.86 \mathrm{fg}$ for Plumes 1, 2 and 3 respectively. We have not quantified $\mathrm{TE}_{\mathrm{BC}}$ in this study, but by dividing the $\mathrm{BC} / \mathrm{CO}$ ratios listed in Table 1 it was $\sim 0.1-0.2$. As the initial size distributions and coatings were different it is difficult to say conclusively whether the removal efficiency was the same between the two studies. The size distributions of $\mathrm{BC}$ remaining after wet removal were qualitatively similar, though the initial and remaining mass distributions were both smaller in this study. What is clear between the two cases is that nucleation scavenging was an effective mechanism for removing coated BC, and that only the smallest particles were left behind. In this study we have also demonstrated that less-coated BC particles are also less effectively removed.

The MMD in Plume 3 was significantly smaller than those measured in remote Pacific air masses by Schwarz et al. (2010b), which were consistently within a few nanometres of $186 \mathrm{~nm}$ (corrected to BC core density of $1.8 \mathrm{gcm}^{-3}$ ). Schwarz et al. (2010b) suggested the consistency (and narrow shape) of this size distribution implied more than one process was responsible for regulating this distribution, one which preferentially removed larger $\mathrm{BC}$ cores and ones which removed smaller BC cores. Considering our results and those of Moteki et al. (2012), it is clear that nucleation scavenging is an effective mechanism for shifting BC core size distributions to smaller sizes. Additional measurements of $\mathrm{BC}$ wet removal in different environments (and involving different mechanisms) are required to further constrain these processes.

The result that wet removal did not significantly affect the SSA and MAC of Plume 3 is important. Many climate models divide $\mathrm{BC}$ into two modes with different hydrophilicity and assume a conversion from the hydrophobic to the hydrophilic mode over time. Bond et al. (2006) recommended a simple optical ageing scheme in which the hydrophobic mode had the optical properties of fresh BC and the hydrophilic had that of aged BC; some models have implemented this scheme (e.g. Goldenson et al., 2012). This was based on the assumption that coatings were the only factor responsible for BC hydrophilicity. In this case study both hydrophobic and hydrophilic BC had similar MAC, as the BC core size distribution was different between the two modes. This provides a point of reference for models and highlights the fact that coatings are not the only factor that affects MAC.

The fact that the SSA was not significantly affected by precipitation suggests that some fraction of nonabsorbing particles also did not activate, presumably because they were too small. For comparison, the mean BC number concentration in Plume 3 was $34 \mathrm{scm}^{-3}$, whereas the mean number concentration of LSPs measured by the SP2 was $718 \mathrm{scm}^{-3}$. A range of hydrophilicity and size-dependent activation ef- ficiency would be expected of all particles, and these results show that BC activated with similar efficiency to LSPs.

\section{Conclusions}

We have presented a case study of black carbon wet removal by comparing three biomass burning plumes from the same region of fires. Through the use of back trajectories and weather satellite data, we identified that one of these plumes convected up into a likely precipitating cloud. The $\mathrm{BC} / \mathrm{CO}$ and $\mathrm{OA} / \mathrm{CO}$ ratios in this plume were much lower than those in the other two plumes and almost all those found in the literature. The only comparable literature values were $\mathrm{BC} / \mathrm{CO}$ ratios in plumes that had also been affected by precipitation. Taken together, the back trajectory, satellite and chemical tracer ratios suggest that most of the aerosol in this plume had been removed by precipitation. By comparing particles in this plume to the two unaffected by precipitation, we have made deductions about the properties of the particles that were rained out.

Upon examination of the bulk size distributions it was clear that the larger particles were preferentially scavenged, meaning nucleation scavenging must have been the wetremoval mechanism. Similarly, the largest and most thickly coated black carbon particles were also removed more efficiently, meaning they must have undergone the same nucleation mechanism. Removing particles with the largest BC cores and also those with the thickest coatings has opposing effects on MAC, and so the calculated values were similar in all three measured plumes. A large number of LSPs were also present in the precipitation-affected plume, so similarly the SSA (based on measured scattering and calculated absorption) was not obviously altered by the precipitation event.

The size dependence of wet removal is an important process for moderating BC lifetime, vertical profile and transport to remote environments. While the observation that larger particles were more efficiently scavenged is similar to those of Moteki et al. (2012), the residual size distribution measured here was smaller. This may be due to thicker coatings on these particles or simply because the original size distribution was smaller than the one described by Moteki et al. (2012). To date there have been very few studies of $\mathrm{BC}$ wet removal. Further measurements of BC wet removal in different environments are required to improve model parameterisations and reduce what is currently a major source of uncertainty in radiative forcing calculations.

\section{The Supplement related to this article is available online at doi:10.5194/acp-14-13755-2014-supplement.}


Acknowledgements. The authors wish to thank all those involved in the BORTAS project. Airborne data were obtained using the BAe-146-301 Atmospheric Research Aircraft (ARA) flown by Directflight Ltd and managed by the Facility for Airborne Atmospheric Measurements (FAAM), which is a joint entity of the Natural Environment Research Council (NERC) and the Met Office. Processed data are available from the British Atmospheric Data Centre. Raw data are archived at the University of Manchester and available on request. BORTAS was supported by NERC under grant number NE/F017391/1 and NE/F017200/1. J. W. Taylor received extra support from the National Centre for Atmospheric Science (NCAS) for travel and subsistence, and J. W. Taylor and M. L. Breton were also supported by NERC $\mathrm{PhD}$ studentships. P. I. Palmer acknowledges financial support from the Leverhulme Trust. We thank Patrick Minnis and Chad Thee at NASA Langley Research Center, USA, for providing the GOES satellite data. The topographical map in Fig. 1 was produced using GTOPO30 data, available at https://lta.cr.usgs.gov/GTOPO30

Edited by: R. MacKenzie

\section{References}

Abel, S. J.: Evolution of biomass burning aerosol properties from an agricultural fire in southern Africa, Geophys. Res. Lett., 30, 1783, doi:10.1029/2003GL017342, 2003.

Akagi, S. K., Craven, J. S., Taylor, J. W., McMeeking, G. R., Yokelson, R. J., Burling, I. R., Urbanski, S. P., Wold, C. E., Seinfeld, J. H., Coe, H., Alvarado, M. J., and Weise, D. R.: Evolution of trace gases and particles emitted by a chaparral fire in California, Atmos. Chem. Phys., 12, 1397-1421, doi:10.5194/acp-12-13972012, 2012.

Allan, J. D., Baumgardner, D., Raga, G. B., Mayol-Bracero, O. L., Morales-García, F., García-García, F., Montero-Martínez, G., Borrmann, S., Schneider, J., Mertes, S., Walter, S., Gysel, M., Dusek, U., Frank, G. P., and Krämer, M.: Clouds and aerosols in Puerto Rico - a new evaluation, Atmos. Chem. Phys., 8, 12931309, doi:10.5194/acp-8-1293-2008, 2008.

Anderson, T. L. and Ogren, J. A.: Determining Aerosol Radiative Properties Using the TSI 3563 Integrating Nephelometer, Aerosol Sci. Tech., 29, 57-69, doi:10.1080/02786829808965551, 1998.

Andreae, M. O. and Merlet, P.: Emission of trace gases and aerosols from biomass burning, Global Biogeochem. Cy., 15, 955-966, doi:10.1029/2000GB001382, 2001.

Baumgardner, D., Subramanian, R., Twohy, C., Stith, J., and Kok, G.: Scavenging of black carbon by ice crystals over the northern Pacific, Geophys. Res. Lett., 35, L22815, doi:10.1029/2008GL035764, 2008.

Baumgardner, D., Popovicheva, O., Allan, J., Bernardoni, V., Cao, J., Cavalli, F., Cozic, J., Diapouli, E., Eleftheriadis, K., Genberg, P. J., Gonzalez, C., Gysel, M., John, A., Kirchstetter, T. W., Kuhlbusch, T. A. J., Laborde, M., Lack, D., Müller, T., Niessner, R., Petzold, A., Piazzalunga, A., Putaud, J. P., Schwarz, J., Sheridan, P., Subramanian, R., Swietlicki, E., Valli, G., Vecchi, R., and Viana, M.: Soot reference materials for instrument calibration and intercomparisons: a workshop summary with recommenda- tions, Atmos. Meas. Tech., 5, 1869-1887, doi:10.5194/amt-51869-2012, 2012.

Bond, T. C. and Bergstrom, R. W.: Light absorption by carbonaceous particles: An investigative review, Aerosol Sci. Tech., 40, 27-67, doi:10.1080/02786820500421521, 2006.

Bond, T. C., Habib, G., and Bergstrom, R. W.: Limitations in the enhancement of visible light absorption due to mixing state, J. Geophys. Res., 111, D20211, doi:10.1029/2006JD007315, 2006.

Bond, T. C., Doherty, S. J., Fahey, D. W., Forster, P. M., Berntsen, T., DeAngelo, B. J., Flanner, M. G., Ghan, S., Kärcher, B., Koch, D., Kinne, S., Kondo, Y., Quinn, P. K., Sarofim, M. C., Schultz, M. G., Schulz, M., Venkataraman, C., Zhang, H., Zhang, S., Bellouin, N., Guttikunda, S. K., Hopke, P. K., Jacobson, M. Z., Kaiser, J. W., Klimont, Z., Lohmann, U., Schwarz, J. P., Shindell, D., Storelvmo, T., Warren, S. G., and Zender, C. S.: Bounding the role of black carbon in the climate system: A scientific assessment, J. Geophys. Res.-Atmos., 118, 1-173, doi:10.1002/jgrd.50171, 2013.

Canagaratna, M. R., Jayne, J. T., Jimenez, J. L., Allan, J. D., Alfarra, M. R., Zhang, Q., Onasch, T. B., Drewnick, F., Coe, H., Middlebrook, A., Delia, A., Williams, L. R., Trimborn, A. M., Northway, M. J., DeCarlo, P. F., Kolb, C. E., Davidovits, P., and Worsnop, D. R.: Chemical and microphysical characterization of ambient aerosols with the aerodyne aerosol mass spectrometer., Mass Spectrom. Rev., 26, 185-222, doi:10.1002/mas.20115, 2007.

Capes, G., Johnson, B., McFiggans, G., Williams, P. I., Haywood, J., and Coe, H.: Aging of biomass burning aerosols over West Africa: Aircraft measurements of chemical composition, microphysical properties, and emission ratios, J. Geophys. Res., 113, D00C15, doi:10.1029/2008JD009845, 2008.

Cappa, C. D., Lack, D. A., Burkholder, J. B., and Ravishankara, A. R.: Bias in filter-based aerosol light absorption measurements due to organic aerosol loading: Evidence from laboratory measurements, Aerosol Sci. Tech., 42, 1022-1032, doi:10.1080/02786820802389285, 2008.

Chung, C. E., Ramanathan, V., and Decremer, D.: Observationally constrained estimates of carbonaceous aerosol radiative forcing., P Natl. Acad. Sci. USA, 109, 11624-11629, doi:10.1073/pnas.1203707109, 2012.

Croft, B., Lohmann, U., Martin, R. V., Stier, P., Wurzler, S., Feichter, J., Posselt, R., and Ferrachat, S.: Aerosol size-dependent below-cloud scavenging by rain and snow in the ECHAM5HAM, Atmos. Chem. Phys., 9, 4653-4675, doi:10.5194/acp-94653-2009, 2009.

Croft, B., Lohmann, U., Martin, R. V., Stier, P., Wurzler, S., Feichter, J., Hoose, C., Heikkilä, U., van Donkelaar, A., and Ferrachat, S.: Influences of in-cloud aerosol scavenging parameterizations on aerosol concentrations and wet deposition in ECHAM5-HAM, Atmos. Chem. Phys., 10, 1511-1543, doi:10.5194/acp-10-1511-2010, 2010.

Crosier, J., Allan, J. D., Coe, H., Bower, K. N., Formenti, P., and Williams, P. I.: Chemical composition of summertime aerosol in the Po Valley (Italy), northern Adriatic and Black Sea, Q. J. Roy. Meteor. Soc., 133, 61-75, doi:10.1002/qj.88, 2007.

Donahue, N. M., Epstein, S. A., Pandis, S. N., and Robinson, A. L.: A two-dimensional volatility basis set: 1. organic-aerosol mixing thermodynamics, Atmos. Chem. Phys., 11, 3303-3318, doi:10.5194/acp-11-3303-2011, 2011. 
Draxler, R. R. and Hess, G. D.: An overview of the HYSPLIT_4 modelling system for trajectories, dispersion and deposition, Aust. Meteorol. Mag., 47, 295-308, 1998.

Drewnick, F., Hings, S. S., DeCarlo, P., Jayne, J. T., Gonin, M., Fuhrer, K., Weimer, S., Jimenez, J. L., Demerjian, K. L., Borrmann, S., and Worsnop, D. R.: A New Time-of-Flight Aerosol Mass Spectrometer (TOF-AMS)- Instrument Description and First Field Deployment, Aerosol Sci. Tech., 39, 637658, doi:10.1080/02786820500182040, 2005.

Duplissy, J., DeCarlo, P. F., Dommen, J., Alfarra, M. R., Metzger, A., Barmpadimos, I., Prevot, A. S. H., Weingartner, E., Tritscher, T., Gysel, M., Aiken, A. C., Jimenez, J. L., Canagaratna, M. R., Worsnop, D. R., Collins, D. R., Tomlinson, J., and Baltensperger, U.: Relating hygroscopicity and composition of organic aerosol particulate matter, Atmos. Chem. Phys., 11, 11551165, doi:10.5194/acp-11-1155-2011, 2011.

Dusek, U., Frank, G. P., Hildebrandt, L., Curtius, J., Schneider, J., Walter, S., Chand, D., Drewnick, F., Hings, S., Jung, D., Borrmann, S., and Andreae, M. O.: Size matters more than chemistry for cloud-nucleating ability of aerosol particles., Science, 312, 1375-1378, doi:10.1126/science.1125261, 2006.

Foltescu, V., Selin, E., and Below, M.: Corrections for particle losses and sizing errors during aircraft aerosol sampling using a rosemount inlet and the PMS LAS-X, Atmos. Environ., 29, 449453, doi:10.1016/1352-2310(94)00258-M, 1995.

Franklin, J. E., Drummond, J. R., Griffin, D., Pierce, J. R., Waugh, D. L., Palmer, P. I., Parrington, M., Lee, J. D., Lewis, A. C., Rickard, A. R., Taylor, J. W., Allan, J. D., Coe, H., Walker, K. A., Chisholm, L., Duck, T. J., Hopper, J. T., Blanchard, Y., Gibson, M. D., Curry, K. R., Sakamoto, K. M., Lesins, G., Dan, L., Kliever, J., and Saha, A.: A case study of aerosol scavenging in a biomass burning plume over eastern Canada during the 2011 BORTAS field experiment, Atmos. Chem. Phys., 14, 8449-8460, doi:10.5194/acp-14-8449-2014, 2014.

Gao, R. S., Schwarz, J. P., Kelly, K. K., Fahey, D. W., Watts, L. A., Thompson, T. L., Spackman, J. R., Slowik, J. G., Cross, E. S., Han, J.-H. H., Davidovits, P., Onasch, T. B., and Worsnop, D. R.: A Novel Method for Estimating LightScattering Properties of Soot Aerosols Using a Modified SingleParticle Soot Photometer, Aerosol Sci. Tech., 41, 125-135, doi:10.1080/02786820601118398, 2007.

Gerbig, C., Schmitgen, S., Kley, D., Volz-Thomas, A., Dewey, K., and Haaks, D.: An improved fast-response vacuum-UV resonance fluorescence CO instrument, J. Geophys. Res., 104, 1699, doi:10.1029/1998JD100031, 1999.

Ghan, S. J., Abdul-Razzak, H., Nenes, A., Ming, Y., Liu, X., Ovchinnikov, M., Shipway, B., Meskhidze, N., Xu, J., and Shi, X.: Droplet nucleation: Physically-based parameterizations and comparative evaluation, Journal of Advances in Modeling Earth Systems, 3, M10 001, doi:10.1029/2011MS000074, 2011.

Giglio, L., Descloitres, J., Justice, C. O., and Kaufman, Y. J.: An Enhanced Contextual Fire Detection Algorithm for \{MODIS \}, Remote Sens. Environ., 87, 273-282, doi:10.1016/S00344257(03)00184-6, 2003.

Goldenson, N., Doherty, S. J., Bitz, C. M., Holland, M. M., Light, B., and Conley, A. J.: Arctic climate response to forcing from light-absorbing particles in snow and sea ice in CESM, Atmos. Chem. Phys., 12, 7903-7920, doi:10.5194/acp-12-7903-2012, 2012.
Gysel, M., Laborde, M., Olfert, J. S., Subramanian, R., and Gröhn, A. J.: Effective density of Aquadag and fullerene soot black carbon reference materials used for SP2 calibration, Atmos. Meas. Tech., 4, 2851-2858, doi:10.5194/amt-4-2851-2011, 2011.

Haywood, J. M. and Shine, K. P.: The effect of anthropogenic sulfate and soot aerosol on the clear sky planetary radiation budget, Geophys. Res. Lett., 22, 603-606, doi:10.1029/95GL00075, 1995.

Hecobian, A., Zhang, X., Zheng, M., Frank, N., Edgerton, E. S., and Weber, R. J.: Water-Soluble Organic Aerosol material and the light-absorption characteristics of aqueous extracts measured over the Southeastern United States, Atmos. Chem. Phys., 10, 5965-5977, doi:10.5194/acp-10-5965-2010, 2010.

Hoose, C. and Möhler, O.: Heterogeneous ice nucleation on atmospheric aerosols: a review of results from laboratory experiments, Atmos. Chem. Phys., 12, 9817-9854, doi:10.5194/acp-12-98172012, 2012.

Jacobson, M. Z.: Development of mixed-phase clouds from multiple aerosol size distributions and the effect of the clouds on aerosol removal, J. Geophys. Res., 108, 4245, doi:10.1029/2002JD002691, 2003.

Khalizov, A. F., Zhang, R., Zhang, D., Xue, H., Pagels, J., and McMurry, P. H.: Formation of highly hygroscopic soot aerosols upon internal mixing with sulfuric acid vapor, J. Geophys. Res., 114, D05208, doi:10.1029/2008JD010595, 2009.

Kirchstetter, T. W. and Thatcher, T. L.: Contribution of organic carbon to wood smoke particulate matter absorption of solar radiation, Atmos. Chem. Phys., 12, 6067-6072, doi:10.5194/acp-126067-2012, 2012.

Koch, D., Schulz, M., Kinne, S., McNaughton, C., Spackman, J. R., Balkanski, Y., Bauer, S., Berntsen, T., Bond, T. C., Boucher, O., Chin, M., Clarke, A., De Luca, N., Dentener, F., Diehl, T., Dubovik, O., Easter, R., Fahey, D. W., Feichter, J., Fillmore, D., Freitag, S., Ghan, S., Ginoux, P., Gong, S., Horowitz, L., Iversen, T., Kirkevåg, A., Klimont, Z., Kondo, Y., Krol, M., Liu, X., Miller, R., Montanaro, V., Moteki, N., Myhre, G., Penner, J. E., Perlwitz, J., Pitari, G., Reddy, S., Sahu, L., Sakamoto, H., Schuster, G., Schwarz, J. P., Seland, Ø., Stier, P., Takegawa, N., Takemura, T., Textor, C., van Aardenne, J. A., and Zhao, Y.: Evaluation of black carbon estimations in global aerosol models, Atmos. Chem. Phys., 9, 9001-9026, doi:10.5194/acp-9-9001-2009, 2009.

Koch, D., Balkanski, Y., Bauer, S. E., Easter, R. C., Ferrachat, S., Ghan, S. J., Hoose, C., Iversen, T., Kirkevåg, A., Kristjansson, J. E., Liu, X., Lohmann, U., Menon, S., Quaas, J., Schulz, M., Seland, Ø., Takemura, T., and Yan, N.: Soot microphysical effects on liquid clouds, a multi-model investigation, Atmos. Chem. Phys., 11, 1051-1064, doi:10.5194/acp-11-1051-2011, 2011.

Koehler, K. A., DeMott, P. J., Kreidenweis, S. M., Popovicheva, O. B., Petters, M. D., Carrico, C. M., Kireeva, E. D., Khokhlova, T. D., and Shonija, N. K.: Cloud condensation nuclei and ice nucleation activity of hydrophobic and hydrophilic soot particles., Phys. Chem. Chem. Phys.: PCCP, 11, 7906-20, doi:10.1039/b905334b, 2009.

Kondo, Y., Matsui, H., Moteki, N., Sahu, L., Takegawa, N., Kajino, M., Zhao, Y., Cubison, M. J., Jimenez, J. L., Vay, S., Diskin, G. S., Anderson, B., Wisthaler, A., Mikoviny, T., Fuelberg, H. E., Blake, D. R., Huey, G., Weinheimer, A. J., Knapp, D. J., and Brune, W. H.: Emissions of black carbon, 
organic, and inorganic aerosols from biomass burning in North America and Asia in 2008, J. Geophys. Res., 116, D08204, doi:10.1029/2010JD015152, 2011.

Laborde, M., Mertes, P., Zieger, P., Dommen, J., Baltensperger, U., and Gysel, M.: Sensitivity of the Single Particle Soot Photometer to different black carbon types, Atmos. Meas. Tech., 5, 10311043, doi:10.5194/amt-5-1031-2012, 2012a.

Laborde, M., Schnaiter, M., Linke, C., Saathoff, H., Naumann, K.H., Möhler, O., Berlenz, S., Wagner, U., Taylor, J. W., Liu, D., Flynn, M., Allan, J. D., Coe, H., Heimerl, K., Dahlkötter, F., Weinzierl, B., Wollny, A. G., Zanatta, M., Cozic, J., Laj, P., Hitzenberger, R., Schwarz, J. P., and Gysel, M.: Single Particle Soot Photometer intercomparison at the AIDA chamber, Atmos. Meas. Tech., 5, 3077-3097, doi:10.5194/amt-5-3077-2012, 2012b.

Lack, D. A., Cappa, C. D., Covert, D. S., Baynard, T., Massoli, P., Sierau, B., Bates, T. S., Quinn, P. K., Lovejoy, E. R., and Ravishankara, A. R.: Bias in filter-based aerosol light absorption measurements due to organic aerosol loading: Evidence from ambient measurements, Aerosol Sci. Tech., 42, 1033-1041, doi:10.1080/02786820802389277, 2008.

Lack, D. A., Langridge, J. M., Bahreini, R., Cappa, C. D., Middlebrook, A. M. and Schwarz, J. P.: Brown carbon and internal mixing in biomass burning particles., Proc. Natl. Acad. Sci. USA., 109, 14802-14807, doi:10.1073/pnas.1206575109, 2012.

Lathem, T. L., Beyersdorf, A. J., Thornhill, K. L., Winstead, E. L., Cubison, M. J., Hecobian, A., Jimenez, J. L., Weber, R. J., Anderson, B. E., and Nenes, A.: Analysis of CCN activity of Arctic aerosol and Canadian biomass burning during summer 2008, Atmos. Chem. Phys., 13, 2735-2756, doi:10.5194/acp-13-27352013, 2013.

Le Breton, M., Bacak, A., Muller, J. B. A., O'Shea, S. J., Xiao, P., Ashfold, M. N. R., Cooke, M. C., Batt, R., Shallcross, D. E., Oram, D. E., Forster, G., Bauguitte, S. J.-B., Palmer, P. I., Parrington, M., Lewis, A. C., Lee, J. D., and Percival, C. J.: Airborne hydrogen cyanide measurements using a chemical ionisation mass spectrometer for the plume identification of biomass burning forest fires, Atmos. Chem. Phys., 13, 92179232, doi:10.5194/acp-13-9217-2013, 2013.

Liggio, J., Gordon, M., Smallwood, G., Li, S.-M., Stroud, C., Staebler, R., Lu, G., Lee, P., Taylor, B., and Brook, J. R.: Are emissions of black carbon from gasoline vehicles underestimated? Insights from near and on-road measurements., Environ. Sci. Tech., 46, 4819-28, doi:10.1021/es2033845, 2012.

Lin, B. and Rossow, W. B.: Precipitation water path and rainfall rate estimates over oceans using special sensor microwave imager and International Satellite Cloud Climatology Project data, J. Geophys. Res., 102, 9359, doi:10.1029/96JD03987, 1997.

Lin, Y.-L., Farley, R. D., and Orville, H. D.: Bulk Parameterization of the Snow Field in a Cloud Model, J. Clim. Appl. Meteorol., 22, 1065-1092, doi:10.1175/15200450(1983)022<1065:BPOTSF>2.0.CO;2, 1983.

Liu, D., Allan, J., Whitehead, J., Young, D., Flynn, M., Coe, H., McFiggans, G., Fleming, Z. L., and Bandy, B.: Ambient black carbon particle hygroscopic properties controlled by mixing state and composition, Atmos. Chem. Phys., 13, 2015-2029, doi:10.5194/acp-13-2015-2013, 2013.

Liu, Y. and Daum, P. H.: Parameterization of the Autoconversion Process.Part I: Analytical Formulation of the Kessler-
Type Parameterizations, J. Atmos. Sci., 61, 1539-1548, doi:10.1175/1520-0469(2004)061<1539:POTAPI>2.0.CO;2, 2004.

Lohmann, U., Stier, P., Hoose, C., Ferrachat, S., Kloster, S., Roeckner, E., and Zhang, J.: Cloud microphysics and aerosol indirect effects in the global climate model ECHAM5-HAM, Atmos. Chem. Phys., 7, 3425-3446, doi:10.5194/acp-7-3425-2007, 2007.

Magi, B. I.: Effects of humidity on aerosols in southern Africa during the biomass burning season, J. Geophys. Res., 108, 8495, doi:10.1029/2002JD002144, 2003.

McMeeking, G. R., Kreidenweis, S. M., Baker, S., Carrico, C. M., Chow, J. C., Collett, J. L., Hao, W. M., Holden, A. S., Kirchstetter, T. W., Malm, W. C., Moosmüller, H., Sullivan, A. P., and Wold, C. E.: Emissions of trace gases and aerosols during the open combustion of biomass in the laboratory, J. Geophys. Res., 114, D19210, doi:10.1029/2009JD011836, 2009.

McMeeking, G. R., Hamburger, T., Liu, D., Flynn, M., Morgan, W. T., Northway, M., Highwood, E. J., Krejci, R., Allan, J. D., Minikin, A., and Coe, H.: Black carbon measurements in the boundary layer over western and northern Europe, Atmos. Chem. Phys., 10, 9393-9414, doi:10.5194/acp-10-9393-2010, 2010.

McNaughton, C. S., Clarke, A. D., Freitag, S., Kapustin, V. N., Kondo, Y., Moteki, N., Sahu, L., Takegawa, N., Schwarz, J. P., Spackman, J. R., Watts, L., Diskin, G., Podolske, J., Holloway, J. S., Wisthaler, A., Mikoviny, T., de Gouw, J., Warneke, C., Jimenez, J., Cubison, M., Howell, S. G., Middlebrook, A., Bahreini, R., Anderson, B. E., Winstead, E., Thornhill, K. L., Lack, D., Cozic, J., and Brock, C. A.: Absorbing aerosol in the troposphere of the Western Arctic during the 2008 ARCTAS/ARCPAC airborne field campaigns, Atmos. Chem. Phys., 11, 7561-7582, doi:10.5194/acp-11-7561-2011, 2011.

Miller, N. and Wang, P.: A theoretical determination of the collection rates of aerosol particles by falling ice crystal plates and columns, Atmos. Environ., Part A, General Topics, 25, 2593 2606, doi:10.1016/0960-1686(91)90177-9, 1991.

Morgan, W. T., Allan, J. D., Bower, K. N., Capes, G., Crosier, J., Williams, P. I., and Coe, H.: Vertical distribution of sub-micron aerosol chemical composition from North-Western Europe and the North-East Atlantic, Atmos. Chem. Phys., 9, 5389-5401, doi:10.5194/acp-9-5389-2009, 2009.

Morgan, W. T., Allan, J. D., Bower, K. N., Highwood, E. J., Liu, D., McMeeking, G. R., Northway, M. J., Williams, P. I., Krejci, R., and Coe, H.: Airborne measurements of the spatial distribution of aerosol chemical composition across Europe and evolution of the organic fraction, Atmos. Chem. Phys., 10, 4065-4083, doi:10.5194/acp-10-4065-2010, 2010.

Moteki, N. and Kondo, Y.: Effects of Mixing State on Black Carbon Measurements by Laser-Induced Incandescence, Aerosol Sci Tech., 41, 398-417, doi:10.1080/02786820701199728, 2007.

Moteki, N., Kondo, Y., and Nakamura, S.: Method to measure refractive indices of small nonspherical particles: Application to black carbon particles, J. Aerosol Sci., 41, 513-521, doi:10.1016/j.jaerosci.2010.02.013, 2010.

Moteki, N., Kondo, Y., Oshima, N., Takegawa, N., Koike, M., Kita, K., Matsui, H., and Kajino, M.: Size dependence of wet removal of black carbon aerosols during transport from the boundary layer to the free troposphere, Geophys. Res. Lett., 39, L13802, doi:10.1029/2012GL052034, 2012. 
Murphy, J. G., Oram, D. E., and Reeves, C. E.: Measurements of volatile organic compounds over West Africa, Atmos. Chem. Phys., 10, 5281-5294, doi:10.5194/acp-10-5281-2010, 2010.

Ng, N. L., Canagaratna, M. R., Zhang, Q., Jimenez, J. L., Tian, J., Ulbrich, I. M., Kroll, J. H., Docherty, K. S., Chhabra, P. S., Bahreini, R., Murphy, S. M., Seinfeld, J. H., Hildebrandt, L., Donahue, N. M., DeCarlo, P. F., Lanz, V. A., Prévôt, A. S. H., Dinar, E., Rudich, Y., and Worsnop, D. R.: Organic aerosol components observed in Northern Hemispheric datasets from Aerosol Mass Spectrometry, Atmos. Chem. Phys., 10, 46254641, doi:10.5194/acp-10-4625-2010, 2010.

O'Shea, S. J., Allen, G., Gallagher, M. W., Bauguitte, S. J.-B., Illingworth, S. M., Le Breton, M., Muller, J. B. A., Percival, C. J., Archibald, A. T., Oram, D. E., Parrington, M., Palmer, P. I., and Lewis, A. C.: Airborne observations of trace gases over boreal Canada during BORTAS: campaign climatology, air mass analysis and enhancement ratios, Atmos. Chem. Phys., 13, 1245112467, doi:10.5194/acp-13-12451-2013, 2013.

Oshima, N., Kondo, Y., Moteki, N., Takegawa, N., Koike, M., Kita, K., Matsui, H., Kajino, M., Nakamura, H., Jung, J. S., and Kim, Y. J.: Wet removal of black carbon in Asian outflow: Aerosol Radiative Forcing in East Asia (A-FORCE) aircraft campaign, J. Geophys. Res., 117, D03204, doi:10.1029/2011JD016552, 2012.

Palmer, P. I., Parrington, M., Lee, J. D., Lewis, A. C., Rickard, A. R., Bernath, P. F., Duck, T. J., Waugh, D. L., Tarasick, D. W., Andrews, S., Aruffo, E., Bailey, L. J., Barrett, E., Bauguitte, S. J.-B., Curry, K. R., Di Carlo, P., Chisholm, L., Dan, L., Forster, G., Franklin, J. E., Gibson, M. D., Griffin, D., Helmig, D., Hopkins, J. R., Hopper, J. T., Jenkin, M. E., Kindred, D., Kliever, J., Le Breton, M., Matthiesen, S., Maurice, M., Moller, S., Moore, D. P., Oram, D. E., O'Shea, S. J., Owen, R. C., Pagniello, C. M. L. S., Pawson, S., Percival, C. J., Pierce, J. R., Punjabi, S., Purvis, R. M., Remedios, J. J., Rotermund, K. M., Sakamoto, K. M., da Silva, A. M., Strawbridge, K. B., Strong, K., Taylor, J., Trigwell, R., Tereszchuk, K. A., Walker, K. A., Weaver, D., Whaley, C., and Young, J. C.: Quantifying the impact of BOReal forest fires on Tropospheric oxidants over the Atlantic using Aircraft and Satellites (BORTAS) experiment: design, execution and science overview, Atmos. Chem. Phys., 13, 6239-6261, doi:10.5194/acp-13-6239-2013, 2013.

Petters, M. D., Parsons, M. T., Prenni, A. J., DeMott, P. J., Kreidenweis, S. M., Carrico, C. M., Sullivan, A. P., McMeeking, G. R., Levin, E., Wold, C. E., Collett, J. L., and Moosmüller, H.: Ice nuclei emissions from biomass burning, J. Geophys. Res., 114, D07209, doi:10.1029/2008JD011532, 2009.

Pratt, K. A., Murphy, S. M., Subramanian, R., DeMott, P. J., Kok, G. L., Campos, T., Rogers, D. C., Prenni, A. J., Heymsfield, A. J., Seinfeld, J. H., and Prather, K. A.: Flight-based chemical characterization of biomass burning aerosols within two prescribed burn smoke plumes, Atmos. Chem. Phys., 11, 1254912565, doi:10.5194/acp-11-12549-2011, 2011.

Ramanathan, V. and Carmichael, G.: Global and regional climate changes due to black carbon, Nat. Geosci., 1, 221-227, doi:10.1038/ngeo156, 2008.

Reid, J. S., Eck, T. F., Christopher, S. A., Koppmann, R., Dubovik, O., Eleuterio, D. P., Holben, B. N., Reid, E. A., and Zhang, J.: A review of biomass burning emissions part III: intensive optical properties of biomass burning particles, Atmos. Chem. Phys., 5, 827-849, doi:10.5194/acp-5-827-2005, 2005a.
Reid, J. S., Koppmann, R., Eck, T. F., and Eleuterio, D. P.: A review of biomass burning emissions part II: intensive physical properties of biomass burning particles, Atmos. Chem. Phys., 5, 799825, doi:10.5194/acp-5-799-2005, 2005 b.

Sahu, L. K., Kondo, Y., Moteki, N., Takegawa, N., Zhao, Y., Cubison, M. J., Jimenez, J. L., Vay, S., Diskin, G. S., Wisthaler, A., Mikoviny, T., Huey, L. G., Weinheimer, A. J., and Knapp, D. J.: Emission characteristics of black carbon in anthropogenic and biomass burning plumes over California during ARCTAS-CARB 2008, J. Geophys. Res., 117, D16302, doi:10.1029/2011JD017401, 2012.

Samset, B. H., Myhre, G., Schulz, M., Balkanski, Y., Bauer, S., Berntsen, T. K., Bian, H., Bellouin, N., Diehl, T., Easter, R. C., Ghan, S. J., Iversen, T., Kinne, S., Kirkevåg, A., Lamarque, J.F., Lin, G., Liu, X., Penner, J. E., Seland, Ø., Skeie, R. B., Stier, P., Takemura, T., Tsigaridis, K., and Zhang, K.: Black carbon vertical profiles strongly affect its radiative forcing uncertainty, Atmos. Chem. Phys., 13, 2423-2434, doi:10.5194/acp-13-24232013, 2013.

Schwarz, J. P., Gao, R. S., Fahey, D. W., Thomson, D. S., Watts, L. A., Wilson, J. C., Reeves, J. M., Darbeheshti, M., Baumgardner, D. G., Kok, G. L., Chung, S. H., Schulz, M., Hendricks, J., Lauer, A., Kärcher, B., Slowik, J. G., Rosenlof, K. H., Thompson, T. L., Langford, A. O., Loewenstein, M., and Aikin, K. C.: Single-particle measurements of midlatitude black carbon and light-scattering aerosols from the boundary layer to the lower stratosphere, J. Geophys. Res., 111, D16207, doi:10.1029/2006JD007076, 2006.

Schwarz, J. P., Gao, R. S., Spackman, J. R., Watts, L. A., Thomson, D. S., Fahey, D. W., Ryerson, T. B., Peischl, J., Holloway, J. S., Trainer, M., Frost, G. J., Baynard, T., Lack, D. A., de Gouw, J. A., Warneke, C., and Del Negro, L. A.: Measurement of the mixing state, mass, and optical size of individual black carbon particles in urban and biomass burning emissions, Geophys. Res. Lett, 35, L13810, doi:10.1029/2008g1033968, 2008.

Schwarz, J. P., Spackman, J. R., Gao, R. S., Perring, A. E., Cross, E., Onasch, T. B., Ahern, A., Wrobel, W., Davidovits, P., Olfert, J., Dubey, M. K., Mazzoleni, C., and Fahey, D. W.: The Detection Efficiency of the Single Particle Soot Photometer, Aerosol Sci. Tech., 44, 612-628, doi:10.1080/02786826.2010.481298, 2010a.

Schwarz, J. P., Spackman, J. R., Gao, R. S., Watts, L. A., Stier, P., Schulz, M., Davis, S. M., Wofsy, S. C., and Fahey, D. W.: Global-scale black carbon profiles observed in the remote atmosphere and compared to models, Geophys. Res. Lett., 37, L18812, doi:10.1029/2010GL044372, 2010b.

Seinfeld, J. H. and Pandis, S. N.: Atmospheric Chemistry and Physics - from Air Pollution to Climate Change, 2nd Edn., John Wiley \& Sons, New York, 1018-1020, 1998.

Slowik, J. G., Cross, E. S., Han, J. H., Davidovits, P., Onasch, T. B., Jayne, J. T., Williams, L. R., Canagaratna, M. R., Worsnop, D. R., Chakrabarty, R. K., Moosmuller, H., Arnott, W. P., Schwarz, J. P., Gao, R. S., Fahey, D. W., Kok, G. L., and Petzold, A.: An inter-comparison of instruments measuring black carbon content of soot particles, Aerosol Sci. Tech., 41, 295-314, doi:10.1080/02786820701197078, 2007.

Stith, J. L., Twohy, C. H., DeMott, P. J., Baumgardner, D., Campos, T., Gao, R., and Anderson, J.: Observations of ice nuclei and heterogeneous freezing in a Western Pacific extratropical storm, 
Atmos. Chem. Phys., 11, 6229-6243, doi:10.5194/acp-11-62292011, 2011.

Stohl, A., Haimberger, L., Scheele, M. P., and Wernli, H.: An intercomparison of results from three trajectory models, Meteorol. Appl., 8, 127-135, 2001.

Sullivan, A. P., Peltier, R. E., Brock, C. A., de Gouw, J. A., Holloway, J. S., Warneke, C., Wollny, A. G., and Weber, R. J.: Airborne measurements of carbonaceous aerosol soluble in water over northeastern United States: Method development and an investigation into water-soluble organic carbon sources, J. Geophys. Res., 111, D23S46, doi:10.1029/2006JD007072, 2006.

Taylor, J. W., Allan, J. D., Liu, D., Flynn, M., Weber, R., Zhang, X., Lefer, B. L., Grossberg, N., Flynn, J., and Coe, H.: Assessment of the sensitivity of core/shell parameters derived using the singleparticle soot photometer to density and refractive index, Atmos. Meas. Tech. Discuss., 7, 5491-5532, doi:10.5194/amtd-7-54912014, 2014.

Taylor, J. W., Allan, J. D., Liu, D., Flynn, M., Hayes, P. L., Jimenez, J. L., Lefer, B. L., Grossberg, N., Flynn, J., Gilman, J., de Gouw, J. A., and Coe, H.: Comparison of measured black carbon mass absorption coefficient to modelled values during CalNex 2010., J. Geophys. Res.-Atmos., in prep., 2015.

Textor, C., Schulz, M., Guibert, S., Kinne, S., Balkanski, Y., Bauer, S., Berntsen, T., Berglen, T., Boucher, O., Chin, M., Dentener, F., Diehl, T., Easter, R., Feichter, H., Fillmore, D., Ghan, S., Ginoux, P., Gong, S., Grini, A., Hendricks, J., Horowitz, L., Huang, P., Isaksen, I., Iversen, I., Kloster, S., Koch, D., Kirkevåg, A., Kristjansson, J. E., Krol, M., Lauer, A., Lamarque, J. F., Liu, X., Montanaro, V., Myhre, G., Penner, J., Pitari, G., Reddy, S., Seland, $\varnothing .$, Stier, P., Takemura, T., and Tie, X.: Analysis and quantification of the diversities of aerosol life cycles within AeroCom, Atmos. Chem. Phys., 6, 1777-1813, doi:10.5194/acp-6-1777-2006, 2006.

Trembath, J., Bart, M., and Brooke, J.: Efficiencies of Modified Rosemount Housings for Sampling Aerosol on a Fast Atmospheric Research Aircraft, FAAM Technical Note, available at: http://www.faam.ac.uk/index.php/component/docman/ doc_download/1673-inlet-efficiency (last access: 24 July 2014), 2012 .
Twohy, C. H., DeMott, P. J., Pratt, K. A., Subramanian, R., Kok, G. L., Murphy, S. M., Lersch, T., Heymsfield, A. J., Wang, Z., Prather, K. A., and Seinfeld, J. H.: Relationships of BiomassBurning Aerosols to Ice in Orographic Wave Clouds, J. Atmos. Sci., 67, 2437-2450, doi:10.1175/2010JAS3310.1, 2010.

Val Martín, M., Honrath, R. E., Owen, R. C., Pfister, G., Fialho, P., and Barata, F.: Significant enhancements of nitrogen oxides, black carbon, and ozone in the North Atlantic lower free troposphere resulting from North American boreal wildfires, J. Geophys. Res., 111, D23S60, doi:10.1029/2006JD007530, 2006.

Vignati, E., Karl, M., Krol, M., Wilson, J., Stier, P., and Cavalli, F.: Sources of uncertainties in modelling black carbon at the global scale, Atmos. Chem. Phys., 10, 2595-2611, doi:10.5194/acp-102595-2010, 2010.

Wang, X., Zhang, L., and Moran, M. D.: Uncertainty assessment of current size-resolved parameterizations for below-cloud particle scavenging by rain, Atmos. Chem. Phys., 10, 5685-5705, doi:10.5194/acp-10-5685-2010, 2010.

Ward, D. E. and Radke, L. F.: Emissions measurements from vegetation fires: A comparative evaluation of methods and results, John Wiley and Sons, Inc.; John Wiley and Sons Ltd., Ward, D. E. Intermountain Res. Station, Forest Serv., US Dep. Agric., P.O. Box 8089, Missoula, MT 59807, USA, 1993.

Yokelson, R. J., Andreae, M. O., and Akagi, S. K.: Pitfalls with the use of enhancement ratios or normalized excess mixing ratios measured in plumes to characterize pollution sources and aging, Atmos. Meas. Tech., 6, 2155-2158, doi:10.5194/amt-62155-2013, 2013.

Zhang, R., Khalizov, A. F., Pagels, J., Zhang, D., Xue, H., and McMurry, P. H.: Variability in morphology, hygroscopicity, and optical properties of soot aerosols during atmospheric processing., P. Natl. Acad. Sci. USA, 105, 10291-10296, doi:10.1073/pnas.0804860105, 2008.

Zhou, J.: Hygroscopic Properties of Atmospheric Aerosol Particles in Various Environments, Doctoral dissertation, Lund University, Lund, ISBN:91-7874-120-3, 14-20, 2001. 